\title{
Cloud and precipitation properties from ground-based remote-sensing instruments in East Antarctica
}

\author{
I. V. Gorodetskaya ${ }^{1}$, S. Kneifel ${ }^{2,3}$, M. Maahn ${ }^{2}$, K. Van Tricht ${ }^{1}$, W. Thiery ${ }^{1}$, J. H. Schween ${ }^{2}$, A. Mangold ${ }^{4}$, S. Crewell ${ }^{2}$, \\ and N. P. M. Van Lipzig ${ }^{1}$ \\ ${ }^{1}$ Department of Earth \& Environmental Sciences, KU Leuven - University of Leuven, Heverlee, Belgium \\ ${ }^{2}$ Institute for Geophysics and Meteorology, University of Cologne, Cologne, Germany \\ ${ }^{3}$ Department of Atmospheric and Oceanic Sciences, McGill University, Montreal, Canada \\ ${ }^{4}$ Observations Department, Royal Meteorological Institute of Belgium, Uccle, Belgium \\ Correspondence to: I. V. Gorodetskaya (irina.gorodetskaya@ees.kuleuven.be)
}

Received: 6 June 2014 - Published in The Cryosphere Discuss.: 28 July 2014

Revised: 23 December 2014 - Accepted: 5 January 2015 - Published: 11 February 2015

\begin{abstract}
A new comprehensive cloud-precipitationmeteorological observatory has been established at Princess Elisabeth base, located in the escarpment zone of Dronning Maud Land (DML), East Antarctica. The observatory consists of a set of ground-based remote-sensing instruments (ceilometer, infrared pyrometer and vertically profiling precipitation radar) combined with automatic weather station measurements of near-surface meteorology, radiative fluxes, and snow height. In this paper, the observatory is presented and the potential for studying the evolution of clouds and precipitating systems is illustrated by case studies. It is shown that the synergetic use of the set of instruments allows for distinguishing ice, liquid-containing clouds and precipitating clouds, including some information on their vertical extent. In addition, wind-driven blowing snow events can be distinguished from deeper precipitating systems. Cloud properties largely affect the surface radiative fluxes, with liquidcontaining clouds dominating the radiative impact. A statistical analysis of all measurements (in total 14 months mainly during summer-beginning of winter) indicates that these liquid-containing clouds occur during as much as $20 \%$ of the cloudy periods. The cloud occurrence shows a strong bimodal distribution with clear-sky conditions $51 \%$ of the time and complete overcast conditions $35 \%$ of the time. Snowfall occurred during $17 \%$ of the cloudy periods with a predominance of light precipitation and only rare events with snowfall $>1 \mathrm{~mm} \mathrm{~h}^{-1}$ water equivalent (w.e.). Three of such intense snowfall events occurred during 2011 contributing to anomalously large annual surface mass balance (SMB).
\end{abstract}

Large accumulation events $\left(>10 \mathrm{~mm}\right.$ w.e. day $\left.^{-1}\right)$ during the radar-measurement period of 26 months were always associated with snowfall, but at the same time other snowfall events did not always lead to accumulation. The multiyear deployment of a precipitation radar in Antarctica allows for assessing the contribution of the snowfall to the local SMB and comparing it to the other SMB components. During 2012, snowfall rate was $110 \pm 20 \mathrm{~mm}$ w.e. $\mathrm{yr}^{-1}$, from which surface and drifting snow sublimation removed together $23 \%$. Given the measured yearly SMB of $52 \pm 3 \mathrm{~mm}$ w.e., the residual term of $33 \pm 21 \mathrm{~mm}$ w.e. $\mathrm{yr}^{-1}$ was attributed to the winddriven snow erosion. In general, this promising set of robust instrumentation allows for improved insight into cloud and precipitation processes in Antarctica and can be easily deployed at other Antarctic stations.

\section{Introduction}

Knowledge of the Antarctic hydrological cycle is essential in order to assess potential future changes of the Antarctic surface mass balance (SMB), which is one of the factors affecting global sea levels (IPCC, 2013; Gregory and Huybrechts, 2006; Krinner et al., 2007; Ligtenberg et al., 2013; Rignot et al., 2011; Uotila et al., 2007; Van den Broeke et al., 2011). Clouds are among the key components of the hydrological cycle, serving as the agents linking water vapour transport into Antarctica with precipitation, determining its amount and spatial distribution. Correct representation of 
cloud condensate amount and phase partitioning in climate models is crucial for simulation of Antarctic precipitation timing and spatial distribution, especially when orographic effects are present (Wacker et al., 2009). Via their radiative forcing, clouds also play a significant role in the Antarctic surface energy balance affecting air and surface temperatures and heat flux exchange of the snow surface with the air above and deeper snow layers (Bintanja and Van den Broeke, 1996; Van den Broeke et al., 2004; Van den Broeke et al., 2006; Vihma et al., 2011). Bennartz et al. (2013) demonstrated a dramatic example of cloud influence on the ice sheet surface energy balance, where radiative forcing of the liquidcontaining clouds coupled with warm air advection was responsible for the surface melt on top of the Greenland ice sheet in July 2012. Liston et al. (1999) pointed out that cloud radiative forcing is a potential player in sub-surface melt water production in the Antarctic near-coastal blue-ice areas.

The extreme environment and climate of the Antarctic ice sheet both lead to unique cloud properties and poses significant difficulties in cloud and precipitation observations. In polar latitudes, low temperatures favour formation of thin ice clouds at all heights including near the surface during the entire year as compared to their occurrence globally only in the upper troposphere (Grenier et al., 2009; Bromwich et al., 2012). Thin ice clouds can have an important effect on the surface and top-of-atmosphere energy balance in the polar regions (Girard and Blanchet, 2001; Lampert et al., 2009). Further, mixed-phase clouds containing supercooled liquid water at air temperatures as low as -38 to $-40^{\circ} \mathrm{C}$ (below which homogeneous ice nucleation occurs) have been observed over the Antarctic ice sheet during short measurement campaigns (Lachlan-Cope, 2010; Walden et al., 2005). Lidar measurements at the near-coastal Antarctic stations also indicated frequent occurrence of liquid-containing clouds (Nott and Duck, 2011). Presence of liquid water has an important effect on cloud radiative properties by increasing cloud optical thickness and long-wave (LW) emissivity (e.g. Turner et al., 2007). It is also an important player in precipitation formation favouring ice particle growth (Hogan et al., 2003a; Morrison and Pinto, 2005; Shupe and Intrieri, 2004; Sun and Shine, 1994). Identifying ice and liquid-containing clouds is thus of high importance for understanding both precipitation processes and energy balance over the Antarctic ice sheet.

Another important challenge in polar climate science is to understand complex mechanisms controlling snow accumulation at different time and spatial scales (Frezzotti et al., 2007, 2013). In particular, this refers to attributing the local and regional accumulation variability to the snowfall and/or drifting/blowing snow. Local snow accumulation is not necessarily driven by precipitation and at the same time precipitation-driven accumulation can be greatly reduced due to the drifting snow erosion (Das et al., 2013; Groot Zwaaftink et al., 2013; Lenaerts et al., 2012a, b). Drifting snow sublimation may also have a significant contribution to the snow ablation especially in the high katabatic wind re- gions (Gallée et al., 2001, 2005; Lenaerts et al., 2012a, b; Thiery et al., 2012).

A new comprehensive observatory on cloudprecipitation-meteorological interactions has been established in the escarpment zone of Dronning Maud Land (DML), East Antarctica, aiming to improve understanding of Antarctic cloud properties and different components of the SMB. The observatory consists of a set of basic and robust ground-based remote-sensing instruments, namely, ceilometer, infrared pyrometer and vertically profiling precipitation radar (presently the only precipitation radar over the Antarctic ice sheet). In addition, an automatic weather station (AWS) provides hourly mean near-surface meteorology, surface radiative fluxes, $1 \mathrm{~m}$ snow temperature profile and snow accumulation (Gorodetskaya et al., 2013). While observatories including similar or more advanced ground-based remote-sensing instruments, with long-term measurements of cloud and precipitation properties, exist in glaciated regions of mid-latitudes and in the Arctic (e.g. Löhnert et al., 2011; Shupe et al., 2011), such observatories have been lacking in Antarctica until now.

The specific combination of ground-based remote-sensing measurements is intended to derive several key cloud and precipitation characteristics, including the vertical structure of clouds and precipitation, cloud base height and temperature, identification of ice-only and liquid-containing clouds, and precipitation intensity. Further, the occurrence of ice virga (precipitation not reaching the surface) and its association with liquid cloud layers can be studied. The combination of the ground-based remote-sensing instruments with an AWS allows for the study of cloud radiative forcing and attributing snow accumulation to precipitation with a potential to distinguish between local accumulation due to snowfall or clear-sky drifting snow. The goal of collecting these data is to perform detailed process-based model evaluation and improve cloud and precipitation parameterisations, required for Antarctic climate simulations (Gallée and Gorodetskaya, 2008; Wacker et al., 2009; Bromwich et al., 2012). Furthermore, the data can be used to evaluate and complement satellite data from similar sensors (e.g. Maahn et al., 2014).

The present paper demonstrates the potential of the observatory by providing detailed case studies and presents statistics of cloud and precipitation properties based on the available measurement periods during 2010-2013. In addition, year-around radar snowfall measurements during 2012 are used for snowfall analysis together with other SMB components. It gives insight about the ice and liquid-containing cloud properties, precipitation intensity and height, contribution of snowfall to SMB, and occurrence of strong blowing snow events. The paper is structured as follows: historical background related to cloud and precipitation measurements is given in Sect. 2; the observatory and data postprocessing are described in Sect. 3; results are provided in Sect. 4, which is subdivided into two parts: case studies and 
long-term series analysis based on the available measurement period; and conclusions are given in Sect. 5.

\section{Historical background}

Observations of clouds and precipitation in Antarctica can be dated back to the first exploratory expeditions, most notably year-round regular meteorological observations during Adrien de Gerlache's expedition on board RV Belgica during 1898-1899 (de Gerlache, 1902) and Roald Amundsen's expedition to the South Pole in 1910-1912 (Amundsen, 1912). During both expeditions, detailed information on cloud amounts, types and snowfall was recorded (Arctowski, 1904; Mohn, 1915). The longest cloud and precipitation records in Antarctica (since 1950s) are available via visual observations of cloudiness, cloud types, precipitation and other weather phenomena at several year-round Antarctic stations (Rusin, 1964; Averianov, 1990; Bryazgin, 1990; Hahn and Warren, 2003; Turner and Pendlebury, 2004). Since the beginning of the satellite era in 1979, cloud occurrence and some properties have been derived from passive satellite observations; however, serious limitations were encountered over ice/snow surfaces (Berque et al., 2011; Lazzara et al., 2003; Town et al., 2007). The launch of active sensors (lidar and radar) on the A-train satellites (Stephens et al., 2002) marks another important step, especially for polar cloud observations, providing vertical profiles of cloud and precipitation microphysical and radiative properties (e.g. Grenier et al., 2009; Winker et al., 2010; Devasthale et al., 2011; Henderson et al., 2013). CloudSat's radar measurements provided an opportunity to estimate the climatology of the Antarctic snowfall (Palerme et al., 2014). Despite tremendous progress in cloud observations from space, limitations in the characterisation of low-level clouds and precipitation persist: they can remain undetected by CloudSat's radar (Marchand et al., 2008; Maahn et al., 2014), while CALIPSO's lidar is rapidly attenuated by cloud liquid water, leaving no information on atmospheric features occurring below the top of the liquid layer (Cesana et al., 2012). Cloud fraction and optical thickness have also been approximated using near-surface broadband LW radiation measurements (Kuipers Munneke et al., 2011; Town et al., 2007; Van den Broeke et al., 2006). Recently available advanced ground-based remote-sensing and airborne measurement techniques provide valuable insights into cloud and precipitation microphysical properties (e.g. Lachlan-Cope, 2010; Lawson et al., 2006; Morley et al., 1989; Walden et al., 2003). These measurements, however, are usually limited to short periods requiring significant maintenance efforts, costs, and power/logistics demands. Ground-based remotesensing instruments, operated during different periods at various locations over the Antarctic ice sheet, provided valuable statistics about cloud and precipitation properties. Information on cloud base height and phase has been ob- tained from lidar measurements at various Antarctic locations (Del Guasta et al., 1993; Shiobara et al., 2003; Mahesh et al., 2005; Nott and Duck, 2011). Ceilometers have been mostly used for aviation reports at several Antarctic stations (e.g. Halley, Neumayer, Novolazarevskaya, South Pole, Terra Nova). Measurements at the South Pole during the entire year of 1992 using ground-based infrared remote-sensing techniques provided information on cloud base heights and optical depths (Mahesh et al., 2001a, b). Observations of snowfall rate were collected year-round in 1989 at Syowa station using ground-based radars and precipitation gauges (Konishi et al., 1998). Bromwich et al. (2012) provided an extensive overview of existing Antarctic cloud data from various measurement techniques.

\section{HYDRANT observatory}

\subsection{Overview}

The Antarctic environment with its especially harsh conditions and difficult accessibility calls for measurements using robust instruments requiring minimal maintenance, but which still provide crucial information on cloud and precipitation properties on a long term. The HYDRANT project (The atmospheric branch of the hydrological cycle in Antarctica) tries to fulfil this demand with its set of ground-based remote-sensing instruments providing high vertical and temporal resolution of cloud and precipitation properties on the long term combined with near-surface meteorological and snow-accumulation measurements. The base for our measurements is the Princess Elisabeth (PE) station built on the Utsteinen Ridge, north of the Sør Rondane mountain chain, in DML, in the escarpment zone of the East Antarctic plateau $\left(71^{\circ} 57^{\prime} \mathrm{S}, 23^{\circ} 21^{\prime} \mathrm{E} ; 1392 \mathrm{~m}\right.$ a.m.s.l., $173 \mathrm{~km}$ from the coast (Fig. 1). Utsteinen Ridge is oriented in a north-south direction and has a length of $700 \mathrm{~m}$, width of approximately $16 \mathrm{~m}$ and protrudes $\sim 20 \mathrm{~m}$ above the surrounding snow surface (Pattyn et al., 2010). Inaugurated in February 2009, the PE base is designed as a zero-emission station relying mostly on wind and solar power. Manned only during summer season (November-February), the station itself and the research instruments are controlled remotely via a year-round satellite connection. Such a concept minimizes local emissions, which can be particularly important not only for boundarylayer aerosol measurements but also for cloud properties downwind due to the role of aerosols in cloud formation and the relatively pristine Antarctic atmosphere.

The measurement site is characterised by a relatively mild climate with a rather high frequency of synoptic events under cyclonic influence and a lack of katabatic drainage of cold air from the plateau due to mountain sheltering (Gorodetskaya et al., 2013). Strong easterly winds are associated with synoptic regimes, while south-southeasterly relatively weak winds are mostly of katabatic origins (Gorodetskaya et al., 


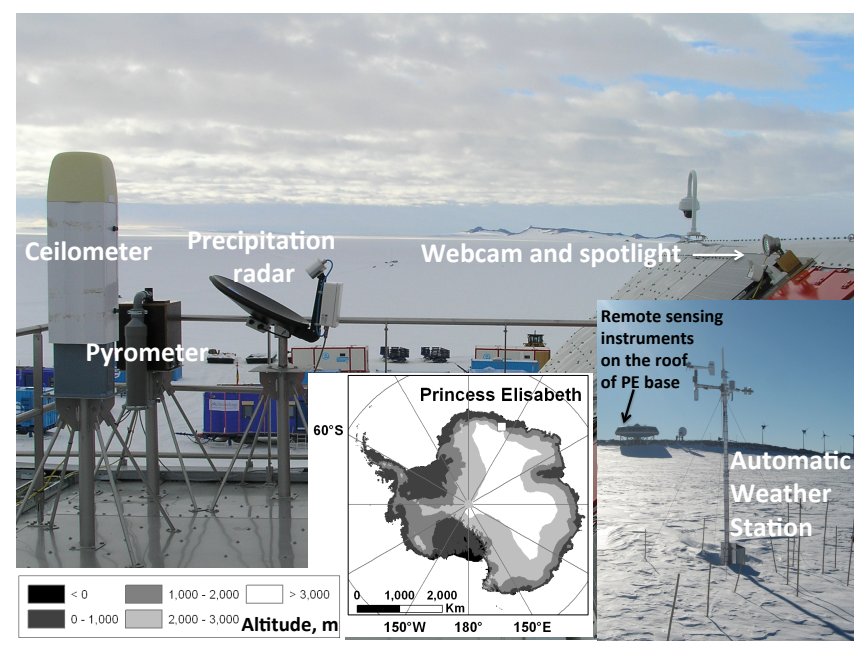

Figure 1. The cloud-precipitation-meteorological observatory HYDRANT at the Princess Elisabeth base in East Antarctica. Shown on the figure are the ceilometer, the infrared pyrometer, the vertically profiling precipitation radar, the webcam with spotlight and the automatic weather station (right lower inset). The middle inset shows the location of the PE station on the Antarctic ice sheet (white square) together with the orography (metres above sea level).

2013). The low katabatic wind speeds together with cloudfree skies lead to significant surface cooling and building up of strong near-surface temperature inversions (Thiery et al., 2012; Gorodetskaya et al., 2013). The site has also large interannual variability in snow accumulation (Pattyn and Decleir, 1993; Pattyn et al., 2010; Gorodetskaya et al., 2013), which for the recent years has been attributed to the different amount of atmospheric rivers reaching DML each year and responsible for the occasional extremely high snowfall and accumulation events (Gorodetskaya et al., 2014).

An overall description of the HYDRANT instruments and their measurement periods are given in Table 1. Detailed descriptions of the cloud and precipitation ground-based remote-sensing instruments and their products are given in Tables 2-4. The instruments include (i) a ceilometer (Table 2), providing vertical profiles of atmospheric attenuated backscatter coefficients from which one can derive cloud base height, cloud vertical structure and information on cloud phase; (ii) an infrared pyrometer (Table 3), providing effective cloud radiative temperature; (iii) a Micro Rain Radar (MRR) (Table 4), providing vertical profiles of spectral signal power, from which one can derive effective reflectivity $Z_{\mathrm{e}}$, mean Doppler velocity of the falling particles, and spectral width. The MRR was originally designed to derive properties of rain (drop-size distribution, rain rate) using a relation between drop sizes and fall speed. Recently, new algorithms have been developed extending MRR application to solid precipitation (Kneifel et al., 2011; Maahn and Kollias, 2012; Colle et al., 2014). In addition, a webcam is installed on the PE roof facing the ground-based instruments and Utsteinen nunatak, providing weather, cloud and instrument monitoring (Table 1, Fig. 1). The present study is based on the data obtained during 2010-2013 with 14 months of cloud measurements mainly during austral summer through beginning of winter and 26 months of snowfall measurements including 1 entire year (see Table 1 for exact periods of data availability). Measurements presently continue and efforts are made to prevent power failures at PE base that have interrupted winter cloud measurements until now.

Cloud and precipitation measurements are combined with AWS measurements providing hourly data on the nearsurface air temperature and relative humidity with respect to ice $\left(\mathrm{RH}_{\mathrm{i}}\right)$, wind speed and direction, pressure, incoming and outgoing LW and short-wave (SW) radiative fluxes, $1 \mathrm{~m}$ snow temperature profile and net snow height changes from a sonic snow height ranger (Table 1). Yearly snow density profile measurements in a $1 \mathrm{~m}$ snow pit (Table 1) are performed every summer season in the AWS vicinity to convert measured snow height changes to water equivalent (w.e.). Snow density varies with depth and the measured density profiles are used to calculate the average snow density over the depth corresponding to the previous year's accumulation. Gorodetskaya et al. (2013) provided detailed information about the AWS instruments and data processing, including snow density measurements.

The project website (http://ees.kuleuven.be/hydrant) contains raw data quick looks, information about the instruments and measurement campaigns, as well as information about available data products. Data are stored as NetCDF files and are freely available upon request via the project website.

\subsection{Remote-sensing data and post-processing methods}

All remote-sensing instruments are installed next to each other on the PE base roof pointing vertically (Fig. 1). Such installation avoids obstacles in the field of view and ensures that different instruments observe an as close as possible volume (see Tables 2-4 for the instruments fields of view). Location on the roof of the base about $10 \mathrm{~m}$ above the ridge also minimizes the instrument view obscurance by shallow drifting snow.

\section{Ceilometer}

The ceilometer (Vaisala CL31), is a single wavelength lidar system without polarisation with emitted laser pulse wavelength of $910 \mathrm{~nm}$ (Table 2, Fig. 1). It reports the attenuated backscatter profile $\left(\beta_{a}=\beta(z) \tau^{2}(z), \mathrm{s} \mathrm{r}^{-1} \mathrm{~m}^{-1}\right)$, derived using the lidar equation by the Vaisala processing system (Münkel et al., 2006; Pal et al., 1992). Here $\beta(z)$ is the true backscatter coefficient at distance $z$ for the wavelength of the emitted laser pulse, and $\tau^{2}(z)$ is the two-way attenuation of the lidar signal due to the transmittance of the atmosphere between the lidar and the scattering volume. Useful reported $\beta_{a}$ profile ranges from 10 up to $7700 \mathrm{~m}$ above 
Table 1. Overview of the HYDRANT instruments: raw measured data, derived parameters, location and continuous measurement periods used for analysis (with data gaps $<3$ days) until 31 December 2013.

\begin{tabular}{|c|c|c|c|}
\hline Instrument & Raw data & Derived parameters & Location and measurement period \\
\hline Ceilometer & $\begin{array}{l}\text { Attenuated } \\
\text { backscatter vertical } \\
\text { profiles }\left(\mathrm{s} \mathrm{r}^{-1} \mathrm{~m}^{-1}\right)\end{array}$ & $\begin{array}{l}\text { Cloud base height } \\
\text { and vertical extent; } \\
\text { cloud phase, } \\
\text { optical depth }\end{array}$ & $\begin{array}{l}\text { PE base roof; } \\
1 / 2-30 / 3 / 2010 ; \\
13 / 1-10 / 4 / 2011 ; \\
14 / 12 / 2011-12 / 3 / 2012 ; \\
1 / 1-16 / 05 / 2013 ; 3-31 / 12 / 2013 \text {. }\end{array}$ \\
\hline $\begin{array}{l}\text { Infrared } \\
\text { radiation } \\
\text { pyrometer }\end{array}$ & $\begin{array}{l}\text { Atmospheric } \\
\text { brightness } \\
\text { temperature }\left({ }^{\circ} \mathrm{C}\right)\end{array}$ & $\begin{array}{r}\text { Effective cloud } \\
\text { base temperature }\end{array}$ & $\begin{array}{l}\text { PE base roof; } \\
15 / 2-24 / 2 / 2010 ; 13 / 1-10 / 4 / 2011 \\
1 / 1-12 / 3 / 2012 ; \\
1 / 1-16 / 05 / 2013 ; 8-31 / 12 / 2013\end{array}$ \\
\hline $\begin{array}{l}\text { Micro Rain } \\
\text { Radar }\end{array}$ & $\begin{array}{l}\text { Spectral signal } \\
\text { power }(\mathrm{mW}) \text { per } \\
\text { range }\end{array}$ & $\begin{array}{r}\text { Effective reflectivity, } \\
\text { spectral width, } \\
\text { mean Doppler } \\
\text { velocity }\end{array}$ & $\begin{array}{l}\text { PE base roof; } \\
\text { 18/01-31/3/2010; } \\
\text { 10/12/2010-10/04/2011; } \\
\text { 4/12/2011-16/5/2013; } \\
\text { 4-31/12/2013. }\end{array}$ \\
\hline $\begin{array}{l}\text { Automatic } \\
\text { Weather } \\
\text { Station }\end{array}$ & $\begin{array}{l}\text { Near-surface air temperature, } \\
\text { relative humidity }(\mathrm{RH}), \text { pressure, } \\
\text { wind speed and direction, } \\
\text { up/down radiative fluxes, } \\
\text { height above snow, } \\
\text { snow temperature profile }\end{array}$ & $\begin{array}{r}\text { RH with respect to ice, } \\
\text { specific humidity, } \\
\text { surface albedo, } \\
\text { surface temperature, } \\
\text { snow accumulation }\end{array}$ & $\begin{array}{l}300 \text { m east of } P E \text { base; } \\
\text { 2/2-21/11/2009; } \\
\text { 12/1-19/10/2010; } \\
9 / 12 / 2010-31 / 12 / 2013\end{array}$ \\
\hline $\begin{array}{l}\text { Webcam } \\
\text { Mobotix } \\
\text { M24 }\end{array}$ & $\begin{array}{l}\text { Jpeg images at } \\
1 \text { min time res; } \\
70 \mathrm{k} \text { res. }\end{array}$ & $\begin{array}{l}\text { Weather and } \\
\text { instrument } \\
\text { monitoring }\end{array}$ & $\begin{array}{l}\text { PE base roof (facing south); } \\
\text { 29/1-10/4/2011; } \\
\text { 14/12/2011-12/3/2012; } \\
\text { 1/1-16/05/2013; 3/12-31/12/2013. }\end{array}$ \\
\hline $\begin{array}{l}\text { Snow pit } \\
\text { equipment }\end{array}$ & $\begin{array}{l}1 \mathrm{~m} \text { profile of snow } \\
\text { density, temperature, } \\
\text { and crystal size/shapes }\end{array}$ & $\begin{array}{l}\text { Snow density profile, } \\
\text { snow metamorphism }\end{array}$ & $\begin{array}{l}\text { Within } 1 \mathrm{~km} \text { east of AWS; } \\
\text { once a year (Dec/Jan) }\end{array}$ \\
\hline
\end{tabular}

ground level (a.g.l.) with $10 \mathrm{~m}$ vertical resolution. The reported $\beta_{a}$ includes range normalisation by multiplying the received ceilometer power with $z^{2}$. It also includes sensitivity normalisation by calibrating the signal with the instrumentspecific factors (Münkel et al., 2006). Percentage of the window transmission is continuously reported and except for strong snowfall events it has been $>99 \%$ maintained by window ventilation and heating. The final Vaisala raw measurement profile of $\beta_{a}$ (at $15 \mathrm{~s}$ temporal resolution) contains noise reduction by summing multiple high-frequency backscatter pulses.

Cloud/precipitation occurrence and base height are identified using the polar threshold (PT) algorithm developed specifically for polar regions (Van Tricht et al., 2014). The algorithm identifies the lowest boundary of a hydrometeor layer including optically thin clouds and precipitation ice layers, frequently observed at low levels. Although the ceilometer does not have polarisation capability, which would provide direct information on the cloud phase, the high backscatter coefficient of the liquid-containing layers together with the rapid extinction of the lidar signal makes it possible to distinguish the liquid-containing clouds as geometrically thin but highly reflective layers (Hogan et al., 2003b). Hogan et al. (2003b) and O'Connor et al. (2004) showed that mid-latitude clouds most likely contain liquid if their optical depth exceeds 0.7 and the peak value of $\beta_{a}$ from a $905 \mathrm{~nm}$ ceilometer is greater than $10^{-4} \mathrm{~s} \mathrm{r}^{-1} \mathrm{~m}^{-1}$. Here we exclude snowfall profiles using MRR measurements (Section 4.2.1) before applying the same threshold to ceilometer $\beta_{a}$ to identify liquidcontaining clouds.

\section{Infrared pyrometer}

The infrared radiation pyrometer (Heitronics KT15.82II) is a passive radiometer measuring the downward radiance within the $8-14 \mu \mathrm{m}$ atmospheric high-transmittance spectral window (Table 3). Atmospheric transmittance ranges from $20 \%$ at the edges up to $80 \%$ within the spectral window in the standard atmosphere (and even higher in Antarctica), thus minimising the absorption due to water vapour, carbon dioxide and ozone. The pyrometer is installed in a heated wooden 
Table 2. Specifications of the HYDRANT ceilometer.

\begin{tabular}{|c|c|}
\hline Instrument & Vaisala CL31 ceilometer \\
\hline Centre wavelength & $910 \pm 10 \mathrm{~nm}$ at $25^{\circ} \mathrm{C}$ \\
\hline Operating mode & $\begin{array}{l}\text { Pulsed, } \\
\text { energy per pulse }=1.2 \mu \mathrm{J} \pm 20 \%\end{array}$ \\
\hline Pulse repetition rate & $10.0 \mathrm{kHz}$ \\
\hline Average emitted power & $12 \mathrm{~mW}$ \\
\hline Beam divergence & $\begin{array}{l} \pm 0.4 \mathrm{mrad} \text { edge } \\
\pm 0.7 \mathrm{mrad} \text { diagonal }\end{array}$ \\
\hline Field-of-view divergence & $\pm 0.83 \mathrm{mrad}$ \\
\hline Measurement resolution & $10 \mathrm{~m}$ (selectable from 10 or $5 \mathrm{~m}$ ) \\
\hline Measurement range & $10-7700 \mathrm{~m}$ \\
\hline Reporting interval & $\begin{array}{c}15 \mathrm{~s} \\
\text { (selectable from } 2 \text { to } 120 \mathrm{~s} \text { ) }\end{array}$ \\
\hline Measurement interval & $\begin{array}{c}2 \mathrm{~s} \text { default } \\
(3 \mathrm{~s} \text { in high-resolution mode })\end{array}$ \\
\hline Environment conditions & $\begin{array}{c}\text { between }-40 \text { and }+60^{\circ} \mathrm{C} \text {, to } 100 \% \mathrm{RH} \text {, } \\
\text { up to } 50 \mathrm{~m} \mathrm{~s}^{-1} \text { wind speed }\end{array}$ \\
\hline Minimum recorded beta & $10^{-8} \mathrm{~s} \mathrm{r}^{-1} \mathrm{~m}^{-1}$ \\
\hline Power consumption & $310 \mathrm{~W}$ (total typical) \\
\hline Protection/shielding & $\begin{array}{l}\text { Optical unit is installed inside } \\
\text { a white protective shield with } \\
\text { automatic lens ventilation } \\
\text { (with heating) and internal heating }\end{array}$ \\
\hline
\end{tabular}

Table 3. Specifications of the HYDRANT infrared pyrometer.

\begin{tabular}{ll}
\hline Instrument & $\begin{array}{l}\text { Heitronics KT15.82 II } \\
\text { Infrared Radiation Pyrometer }\end{array}$ \\
\hline Spectral response & $8-14 \mu \mathrm{m}$ \\
Lens & $\mathrm{K} 6$, detector type A, \\
& material Ge \\
Temperature measuring range & $-100-+50^{\circ} \mathrm{C}$ \\
Temperature resolution & $0.15^{\circ} \mathrm{C}$ at $T-25^{\circ} \mathrm{C}$ \\
(emissivity 1, response time $1 \mathrm{~s})$ & $0.05^{\circ} \mathrm{C}$ at $T+20^{\circ} \mathrm{C}$, \\
Accuracy (uncertainty) & $\pm 0.5^{\circ} \mathrm{C}+0.7 \%$ \\
& of the difference between \\
& target and ambient temperature \\
& $18 \mathrm{~mm}$ \\
Optical field of view (f-120 mm) & at $1 \mathrm{~mm}$ distance from lens \\
& $300 \mathrm{~mm}$ \\
& at $8 \mathrm{~m}$ distance from lens \\
& $5 \mathrm{~Hz}$ \\
Sample rate & between -20 and $+60^{\circ} \mathrm{C}$ \\
Operational temperature range & Wooden protective housing with \\
Protection/shielding & inside temperature at $+15^{\circ} \mathrm{C}$ \\
& and continuous lens ventilation \\
\hline
\end{tabular}

box with continuous lens ventilation to prevent lens contamination and blockage due to snow (Fig. 1).

For optically thick clouds the pyrometer temperature $\left(T_{\mathrm{pyr}}\right.$, ${ }^{\circ} \mathrm{C}$ ) is determined by the infrared emission within the lowest part of the cloud. Though this is typically slightly colder than the temperature at cloud base, compensation by atmospheric emission below cloud base allows us to approximate $T_{\text {pyr }}$ as being equal to the cloud base temperature. At the same time, for clouds residing within a temperature inversion, as frequently occurring in both polar regions (e.g. Mahesh et al., 2001a, b; Sedlar et al., 2012), the cloud emit-
Table 4. Specifications of the HYDRANT Micro Rain Radar.

\begin{tabular}{|c|c|}
\hline Instrument & $\begin{array}{l}\text { METEK Micro Rain } \\
\text { Radar } 2 \text { (MRR) }\end{array}$ \\
\hline Operating mode & FMCW* Doppler \\
\hline Spatial coverage & Vertically profiling \\
\hline Centre frequency & $24.23 \mathrm{GHz}(\lambda=1.24 \mathrm{~cm})$ \\
\hline Frequency modulation & $\begin{array}{l}0.5-15 \mathrm{MHz} \text { range } \\
\text { resolution dependent }\end{array}$ \\
\hline Nominal transmit power & $50 \mathrm{~mW}$ \\
\hline Antenna dish & $\begin{array}{l}\text { Offset parabolic } \\
\text { dish, } \varnothing=60 \mathrm{~cm}\end{array}$ \\
\hline Beam width (two-way, $6 \mathrm{~dB}$ ) & $1.5^{\circ}$ \\
\hline Measurement range & $\begin{array}{l}100 \mathrm{~m}-3.1 \mathrm{~km} \\
\text { (at } 100 \mathrm{~m} \text { resolution) }\end{array}$ \\
\hline Measurement resolution & $\begin{array}{l}100 \mathrm{~m} \\
\text { (selectable from } 30 \mathrm{~m} \text { to } 300 \mathrm{~m} \text { ) }\end{array}$ \\
\hline Reporting interval & $10 \mathrm{~s}$ \\
\hline Environment conditions & $\begin{array}{l}\text { Operational between } \\
-40 \text { and }+60^{\circ} \mathrm{C} \text {; } \\
\text { wind speeds up to } 45 \mathrm{~m} \mathrm{~s}^{-1}\end{array}$ \\
\hline Power consumption & $25 \mathrm{~W}$ \\
\hline Installation set up & $\begin{array}{l}\text { Natural ventilation of the } \\
\text { antenna dish; no antenna heating }\end{array}$ \\
\hline
\end{tabular}

* Frequency-modulated continuous-wave

ting layer is shifted towards the cloud top, in which case $T_{\text {pyr }}$ will exceed the cloud base temperature. Rathke et al. (2002) showed overall good correspondence between the effective cloud radiative temperatures obtained from the geometric and spectral methods versus the lidar/radiosonde values of cloud base temperatures for Arctic stratus clouds. Deviations were attributed mostly to cloud inhomogeneity, in particular variable cloud water content, and to presence of strong in-cloud temperature gradients. For optically thinner clouds, both the temperature profile and variable cloud optical thickness strongly influence cloud emitted radiances and therefore the observed $T_{\mathrm{pyr}}$. Measurements in Antarctica show predominance of optically thin clouds (cloud optical depth $<1$ ) over the Antarctic plateau (Mahesh et al., 2001b), and frequent optically thick clouds at the Antarctic coast (Ricchiazzi et al., 1995). Here, we use raw $T_{\text {pyr }}$ measurements at $1 \mathrm{~min}$ temporal resolution without distinguishing between optically thin and thick clouds.

\section{Precipitation radar}

The radar (METEK MRR-2) is a frequency-modulated continuous-wave vertically profiling Doppler radar, transmitting at $24 \mathrm{GHz}$ frequency $(\lambda=1.24 \mathrm{~cm})$ by a $50 \mathrm{~mW}$ solid state transmitter and focused by a $60 \mathrm{~cm}$ offset parabolic antenna (Table 4; Fig. 1). The low power consumption of MRR makes it suitable for installation at PE and other remote regions. Antenna heating was not used at PE due to the inefficiency in flushing down of melted snow particles of 
rather small size and the risk of the antenna dish glaciation during the unmanned winter period. Instead, the MRR was installed such that to assure natural ventilation of the antenna dish, which proved to be efficient as snowfall at PE is almost always accompanied by strong winds. Occasional formation of a thin snow layer causes no disturbance to the measurements as attenuation by dry snow is very weak in the K-band (Matrosov, 2007).

Maahn and Kollias (2012) improved the MRR raw signal processing for solid precipitation, providing reliable values of radar effective reflectivity $\left(Z_{\mathrm{e}}, \mathrm{mm}^{6} \mathrm{~m}^{-3}\right.$, expressed also in $\left.\mathrm{dBz}=10 \log _{10} Z_{\mathrm{e}}\right)$, mean Doppler velocity $\left(\mathrm{m} \mathrm{s}^{-1}\right)$ and velocity spectral width $\left(\mathrm{m} \mathrm{s}^{-1}\right)$, the latter characteristic of turbulence and variability of fall speed due to particle form and size. Useful reported precipitation profiles range from 400 up to $3000 \mathrm{~m}$ a.g.l. with $100 \mathrm{~m}$ vertical resolution. Sensitivity down from -8 to $-3 \mathrm{dBz}$, depending on range, allows the MRR to detect rather weak precipitation-size particles, but is insensitive to small cloud particles. MRR sensitivity near the surface is close to the commonly used threshold of $-10 \mathrm{dBz}$ to identify precipitation from $35 \mathrm{GHz}$ radar (Wang and Sassen, 2001).

Photographs of the fallen snow crystals at PE in February 2010 and January 2011 revealed a maximum size of $0.5-$ $0.8 \mathrm{~mm}$, represented mostly by dendrites, columns, capped columns and rosettes. This is comparable to the snowfall particle shapes and sizes $(0.03-0.6 \mathrm{~mm})$ measured at other Antarctic locations (Gay et al., 2002; Konishi et al., 1998; Lachlan-Cope et al., 2001; Walden et al., 2003). The total echo power is dominated by the largest particles according to the Rayleigh scattering regime, although some of the larger falling snow particles might slightly deviate from pure Rayleigh scattering at MRR wavelength (Field et al., 2005; Kneifel et al., 2011).

In addition to snowfall, MRR can also detect ice virga, defined as streaks of ice particles falling out of a cloud but evaporating before reaching the earth's surface as precipitation (AMS, 2014). Ice virga below mid-latitude altocumulus clouds is characterised by rather low number concentrations of ice crystals with particle sizes $\sim 0.15-0.25 \mathrm{~mm}$ and $35 \mathrm{GHz}$ radar $Z_{\mathrm{e}}$ ranging between -20 and $0 \mathrm{dBz}$ (Wang et al., 2004; Westbrook and Illingworth, 2013). While MRR misses the most feeble precipitation (virga or snowfall) with $Z_{\mathrm{e}}<-8 \mathrm{dBz}$, its sensitivity is sufficient to detect typical precipitation at the site.

In order to compare with snow accumulation on the ground, we use $Z_{\mathrm{e}}$ at $400 \mathrm{~m}$ a.g.l. to derive hourly mean snowfall rate $\left(S, \mathrm{~mm}\right.$ w.e. $\left.\mathrm{h}^{-1}\right)$. Variability in snow particle shapes, size distributions, densities, and fall velocities results in large uncertainty in the $Z_{\mathrm{e}}-S$ relationships. We calculate $S$ range using nine relationships derived for dry (unrimed) snowfall and typical snow particle shapes for 34.6$35 \mathrm{GHz}$ radar frequency (Table 5). Six relationships were derived by Matrosov (2007) for aggregate snowflakes modelled as spheroids of variable aspect ratio, mass and fall veloc-
Table 5. $Z_{\mathrm{e}}-S$ relationships $\left(Z_{\mathrm{e}}\right.$ in $\mathrm{mm}^{6} \mathrm{~m}^{-3}, S$ in mm w.e. $\left.\mathrm{h}^{-1}\right)$ for dry (unrimed) snow for various snowfall particle shapes and parameters.

\begin{tabular}{lc}
\hline $\begin{array}{l}\text { Ice habit } \\
\text { or parameters }\end{array}$ & $\begin{array}{c}Z_{\mathrm{e}}-S \\
\text { relationships }\end{array}$ \\
\hline Three-bullet rosettes * & $Z_{\mathrm{e}}=24.04 S^{1.51}$ \\
Aggregates * & $Z_{\mathrm{e}}=313.29 S^{1.85}$ \\
Low-density spheres * & $Z_{\mathrm{e}}=19.66 S^{1.74}$ \\
Aggregate spheroids ** & $Z_{\mathrm{e}}=56 S^{1.2}$ \\
- increasing $r^{* *}$ & $Z_{\mathrm{e}}=34 S^{1.1}$ \\
- increasing (decreasing) $m^{* *}$ & $Z_{\mathrm{e}}=66 S^{1.2}\left(Z_{\mathrm{e}}=48 S^{1.2}\right)$ \\
- increasing (decreasing) $V_{t}^{* *}$ & $Z_{\mathrm{e}}=46 S^{1.2}\left(Z_{\mathrm{e}}=67 S^{1.2}\right)$ \\
\hline
\end{tabular}

* Relationships derived by Kulie and Bennartz (2009) using different ice habit models and their backscattering characteristics at $35 \mathrm{GHz} ;{ }^{* *}$ Relationships derived by Matrosov (2007) for aggregated snowflakes approximated as spheroids using various assumptions on particle radius $(r)$, mass $(m)$-size relations, and fall velocity $\left(V_{t}\right)$-size relations at $34.6 \mathrm{GHz}$.

ity. Furthermore, Kulie and Bennartz (2009) derived $Z_{\mathrm{e}}-S$ relationships for a large ensemble of snow particle habits and size distributions to obtain global estimates of snowfall rate from satellite radar data. They selected three relations (for aggregates, three-bullet rosettes and low-density spherical snow particles), which they found to represent best the overall uncertainty range of their particle ensemble. All chosen relationships are representative of dry snowfall (i.e. snow particles are not significantly rimed or melted) and their scattering models of particle habits and sizes are very similar to observed particles at various Antarctic locations, e.g. Syowa and South Pole (Konishi et al., 1998; Walden et al., 2003). Thus, we assume that the expected $S$ value lies within the predicted range. To reduce the uncertainty, measurements of snow particle shapes and sizes are required during each snowfall. The uncertainty of applying $Z_{\mathrm{e}}-S$ relationships derived for $35 \mathrm{GHz}$ radar to $24 \mathrm{GHz}$ MRR is negligible for small snow particles typically occurring in Antarctica (Kneifel et al., 2011).

\section{Results}

\subsection{Case studies}

\subsubsection{Synoptic evolution}

In order to demonstrate the complementary nature of HYDRANT measurements and their utility for detailed process studies, this section presents analyses of several cases representative for different cloud and precipitation types (liquidcontaining clouds, ice clouds, ice virga, and precipitation to the surface) that occurred during the week of 6-13 February 2012. Using the European Centre for Medium-Range Weather Forecasts Interim re-analysis data (ERA-Interim) (Dee et al., 2011), local measurements are analysed in re- 


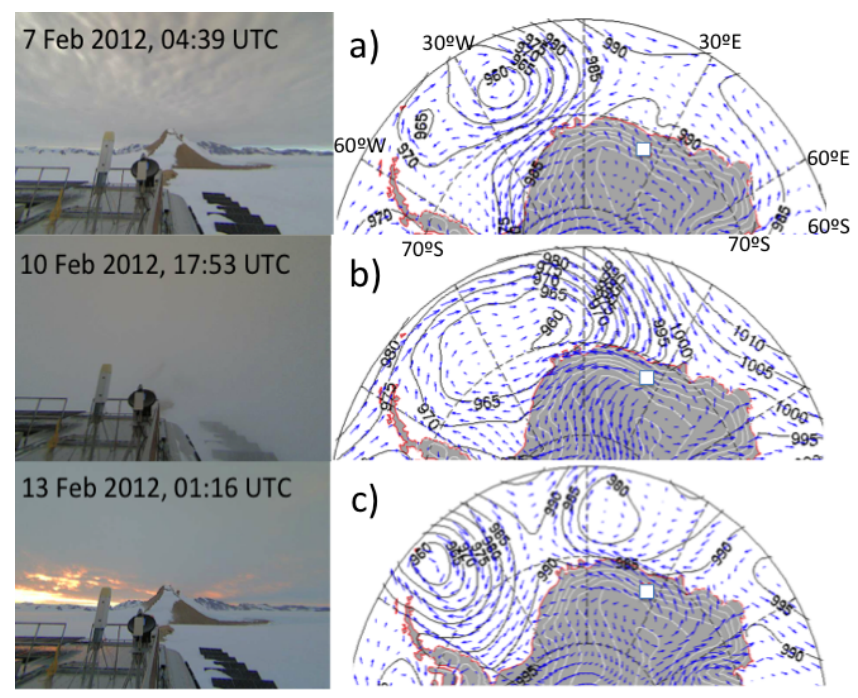

Figure 2. Webcam sky images at specified day and UTC time (left) and maps of corresponding daily mean sea level pressure (contours) and $10 \mathrm{~m}$ wind speed and direction (arrows) from ERAInterim re-analysis data (right) during (a) 7 February 2012 (case 1), (b) 10 February 2012 (case 2), and (c) 13 February 2012 (case 3). The white square indicates the position of PE base. See also webcam movies for each case in the Supplement.

lationship to synoptic weather systems and their temporal evolution. Meteorological regime classification for each case follows the method of Gorodetskaya et al. (2013).

During the whole week of 6-13 February 2012, PE was under the influence of passing cyclones with three distinct cases characterised by various cloud and precipitation properties. Figure 2 shows the synoptic situation evolution and local weather at PE captured by the webcam (see also Supplement for the movies produced using $1 \mathrm{~s}$ webcam images). The beginning of the period (6-7 February) was associated with a wide low pressure system centred at $65^{\circ} \mathrm{S}, 20^{\circ} \mathrm{W}$ (east of the Weddell Sea), and was characterised by stratocumulus cloud appearance at PE (Fig 2a; case 1). On 10 February, the cyclone extended with its eastern flank reaching $30^{\circ} \mathrm{E}$, while the centre remained almost at the same position $\left(68^{\circ} \mathrm{S}, 20^{\circ} \mathrm{W}\right)$. A high-pressure ridge blocking on the east was steering a strong moisture flow into the DML resulting in two intense snowfall events at PE (Fig 2b; case 2). The webcam images during this case show an overcast sky and reduced visibility. Finally, on 13 February 2012 the cyclone centre moved to $8^{\circ} \mathrm{E}$ (King Haakon VII Sea) bringing ice and liquid-containing clouds with virga and a weak snowfall to PE (Fig 2c; case 3). The webcam image around 01:00 UTC on this day shows the arrival of overcast conditions with the night sun visible in a small opening at the horizon (Fig 2c). We finish the process studies with a separate case on 8 April 2013 demonstrating a strong blowing snow event during a cloud-free katabatic regime day (case 4).

\subsubsection{Case 1: liquid-containing clouds}

On 6-7 February 2012, persistent liquid-containing stratocumulus clouds were observed over PE for almost $30 \mathrm{~h}$ with an important impact on radiative fluxes. Ceilometer measurements reveal a two-layer cloud structure (Fig. 3a): a thin highly reflective layer with $\beta_{a}>10^{-4} \mathrm{~s} \mathrm{r}^{-1} \mathrm{~m}^{-1}$, indicating the presence of liquid, occurred at $2-2.5 \mathrm{~km}$ a.g.l. height, with an intermittent ice layer below $\left(10^{-6.5}<\beta_{a}<\right.$ $10^{-5} \mathrm{~s} \mathrm{r}^{-1} \mathrm{~m}^{-1}$ ) extending down to $500 \mathrm{~m}$ a.g.l. Such mixedphase cloud structure consisting of a liquid-containing layer on top with an ice layer below is frequently observed in midlatitudes and in the Arctic (Gayet et al., 2009; Shupe et al., 2006; Verlinde et al., 2007; Wang et al., 2004; Westbrook and Illingworth, 2013). The lower ice part of the cloud was not detected by MRR, indicating that the ice layer was characterised by small non-precipitating particles (Fig. 3b, c). The mixed-phase cloud had a strong effect on $T_{\mathrm{pyr}}$, which was peaking between -30 and $-20^{\circ} \mathrm{C}$ during the cloud presence compared to $-80^{\circ} \mathrm{C}$ during clear-sky periods (Fig. 3d). The highest $T_{\text {pyr }}$ observed at around the same time (13:00 UTC) on both 6 and 7 February was associated with a liquid cloud layer; however, on 6 February the liquid layer was located at lower elevation (1.8 km a.g.1.) compared to $2.6 \mathrm{~km}$ a.g.l. on 7 February. The extended layer of ice observed below the liquid layer on 7 February occurred together with a substantial increase in $T_{\text {pyr }}$ (Fig. 3d).

A strong impact on surface radiative fluxes and consequently on surface and air temperature is one of the important characteristics of liquid-containing clouds over the Antarctic ice sheet. The increase in the surface incoming LW flux $\left(\mathrm{LW}_{\text {in }}\right)$ is tremendous: from $160 \mathrm{~W} \mathrm{~m}^{-2}$ during clear sky up to $240 \mathrm{~W} \mathrm{~m}^{-2}$ during the cloud presence. Changing cloud properties cause significant variability in the cloud radiative effect: the increase in elevation of the liquid-containing layer from 1.8 to $2.5 \mathrm{~km}$ a.g.l. lead to $\sim 20 \%$ decrease in $\mathrm{LW}_{\text {in }}$ (Figs. $3 \mathrm{a}$ and $4 \mathrm{a}$ ). At the same time, $\mathrm{LW}_{\text {in }}$ increases again during the presence of an extended ice layer below the liquid layer after 12:00 UTC on 7 February. Simultaneously enhanced ice production below a liquid layer and increased $T_{\mathrm{pyr}}$ and $\mathrm{LW}_{\text {in }}$ could be manifestations of increased cloud liquid water path. Liquid-containing cloud strongly increased $\mathrm{LW}_{\text {in }}$ and reduced net SW (up to $20 \mathrm{~W} \mathrm{~m}^{-2}$ difference at noon UTC). This resulted in a rather smooth daily cycle of the near-surface air temperature with warmer nights and colder days (Fig. 4c).

\subsubsection{Case 2: frontal clouds and intense snowfall}

From 8 to 11 February 2012, ceilometer and MRR profiles (Fig. 3a-c) show cloud and precipitation properties typical of a warm frontal system passage resulting in the noon near-surface air temperature increase from $-10^{\circ} \mathrm{C}$ before the storm up to $-5^{\circ} \mathrm{C}$ afterwards (Fig. 4c). First, optically thin ice cirrus clouds appear near $6 \mathrm{~km}$ a.g.l. in the very end 


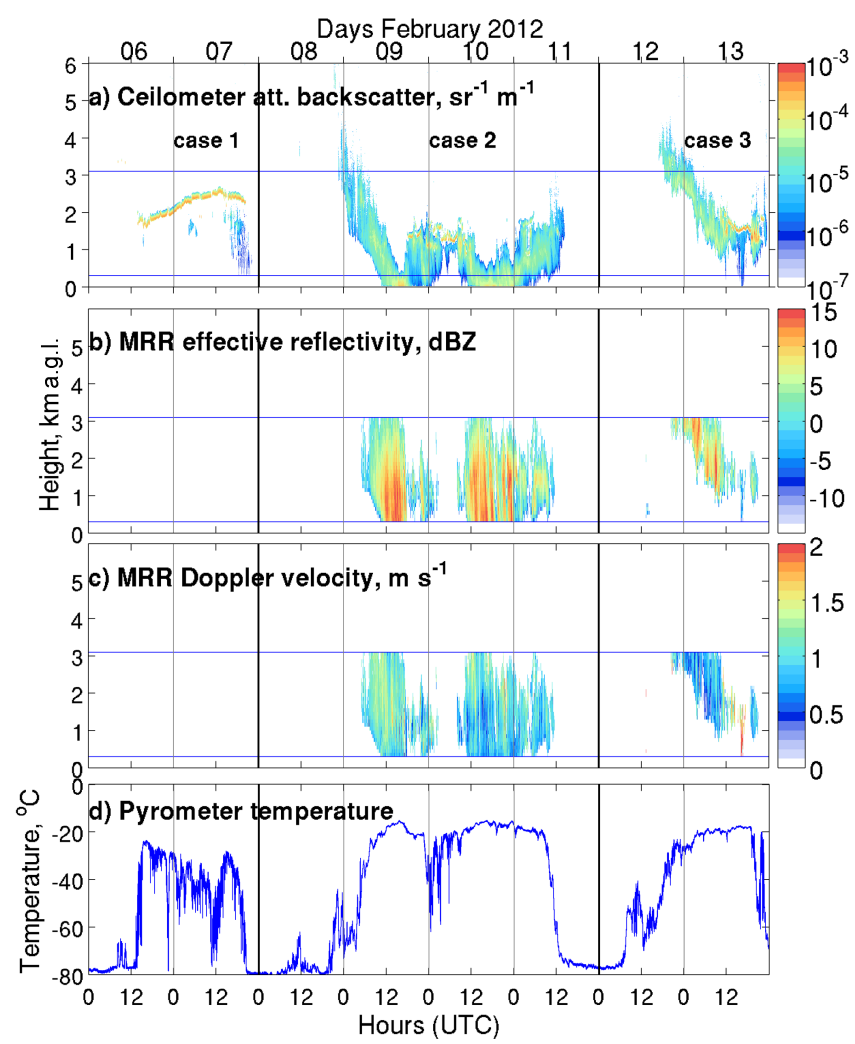

Figure 3. Cloud and precipitation properties derived from groundbased remote-sensing instruments during the case studies period 6-13 February 2012: (a) ceilometer attenuated backscatter profiles, (b) MRR radar effective reflectivity profiles, (c) MRR mean Doppler velocity profiles, and (d) infrared pyrometer temperature. Horizontal blue lines depict the MRR profile limits from 400 to $3100 \mathrm{~m}$ a.g.l. Vertical black lines delimit cases.

of 8 February followed by the arrival of mid-level clouds (possibly altrostratus) on 9 February decreasing in height and producing a virga and shortly after an intense snowfall to the ground completely attenuating the ceilometer signal (Fig. 3a). MRR $Z_{\mathrm{e}}$ profiles show that precipitation extended at least up to $3 \mathrm{~km}$ a.g.l. (Fig. $3 \mathrm{~b}$ and c). Despite the ceilometer signal attenuation by snowfall, it can be used to extend the MRR-derived precipitation profile starting at $400 \mathrm{~m}$ a.g.l. down to the surface (see the ceilometer signal below the horizontal blue line near the surface in Fig. 3a). During the precipitation gap from 9 to 10 February, low-level mixed-phase clouds became visible, followed by another intense and deep snowfall in the afternoon of 10 February. On 11 February, the snowfall weakened, followed by low-level virga layers and a short period of low-level ice clouds (with upper boundaries below $2 \mathrm{~km}$ a.g.l.) ending in a clear-sky afternoon.

The $T_{\mathrm{pyr}}$ shows high sensitivity to cloud and precipitation occurrence (however, during snowfall signal disturbances are expected) (Fig. 3d). Appearance of thin ice clouds above $3 \mathrm{kma.g} .1$. on 8 February preceding the storm results in a $T_{\text {pyr }}$ jump up to $-45^{\circ} \mathrm{C}$ (Fig. 3d) with a $20 \mathrm{~W} \mathrm{~m}^{-2}$ increase
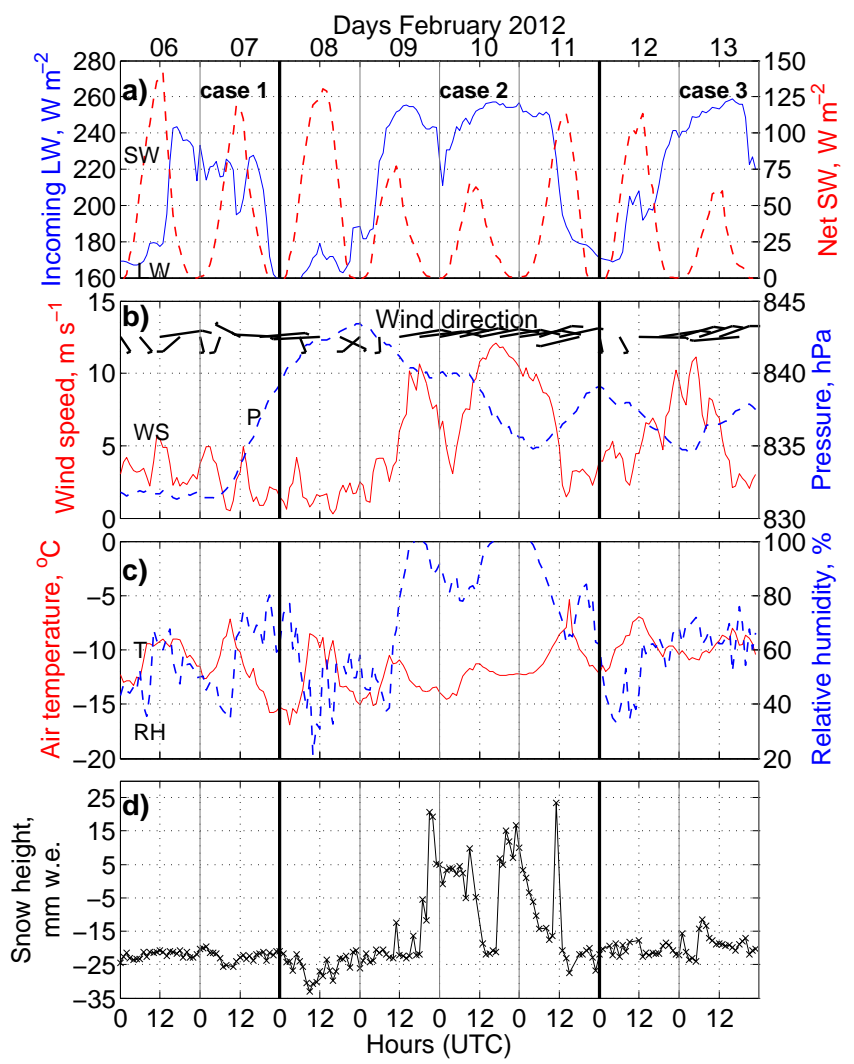

Figure 4. Hourly meteorological parameters during the case studies period 6-13 February 2012: (a) incoming long-wave (LW) and net short-wave (SW) fluxes, (b) wind speed (WS), wind direction (indicated by "hockey sticks"), and local pressure $(P),(\mathbf{c})$ near-surface air temperature $(T)$ and relative humidity with respect to ice $\left(\mathrm{RH}_{\mathrm{i}}\right)$, and (d) snow height relative to 1 January 2012, 00:00 UTC.

in $L W_{\text {in }}$ (Fig. 4a). This shows the potential of the observatory to investigate the radiative importance of optically thin high-level cirrus clouds, despite the decrease of ceilometer sensitivity with height (Van Tricht et al., 2014).

The observed cloud and precipitation properties cause a large variability of $\mathrm{LW}_{\text {in }}$ with an increase up to $255 \mathrm{~W} \mathrm{~m}^{-2}$ during low-level cloudiness and precipitation, and an almost 2-fold reduction in the net SW flux during the peak insolation hours (Fig. 4a). Periods of snowfall occurred together with intensified wind speeds and wind direction changing from southerly to easterly (Fig. 4b), which is characteristic of a synoptic weather regime at PE (Gorodetskaya et al., 2013). The increase of $\mathrm{RH}_{\mathrm{i}}$ to $100 \%$ provides an additional indication of snow present in the boundary layer (Fig. 4c). The snowfall periods were determined based on the MRR $Z_{\mathrm{e}}$ observations at $400 \mathrm{~m}$ a.g.l. level exceeding $-8 \mathrm{dBz}$ : from 12:00 UTC to 00:00 UTC of 9 February for the first and 11:00 UTC 10 February to 06:00 UTC 11 February for the second snowfall event. Significant snow accumulation (up to $30 \mathrm{~mm}$ w.e. during the first snowfall period and $40 \mathrm{~mm}$ w.e. during the second snowfall) was followed by snow removal 
resulting in zero total accumulation over the 3-day period (Fig. 4d). Snow removal was associated with strong winds with hourly mean wind speed up to $12 \mathrm{~m} \mathrm{~s}^{-1}$ (Fig. 4b).

\subsubsection{Case 3: frontal clouds, virga and weak snowfall}

The case on 12-14 February 2012 highlights the role of liquid-containing clouds in precipitation formation and radiative forcing. Similarly to case 2 , ceilometer and MRR profiles (Figs. 3a-c) show cloud and precipitation properties typical for a warm frontal system passage: it starts with arrival of high-level optically thin ice cirrus around noon of 12 February, causing an increase in $T_{\mathrm{pyr}}$ from $-80^{\circ} \mathrm{C}$ to $-40^{\circ} \mathrm{C}$. Further cloud properties are somewhat different from case 2: mid-level clouds with virga last longer, with decreasing cloud base height, thickening into a low-level nimbostratus (Ns) cloud bringing weak snowfall. The Ns cloud was characterised by formation of a geometrically thin and highly reflective layer (with $\beta_{a}>10^{-4} \mathrm{~s} \mathrm{r}^{-1} \mathrm{~m}^{-1}$ ) indicating the presence of liquid at $1.5 \mathrm{~km}$ a.g.l. and an increase in $T_{\mathrm{pyr}}$ up to $-20^{\circ} \mathrm{C}$ (Fig. 3d).

In the morning of 13 February, radar $Z_{\mathrm{e}}$ (Fig. 3b) shows higher vertical extent (at least up to $3 \mathrm{~km}$ ) compared to the ceilometer $\beta_{a}$ (Fig. 3a). The latter is attenuated by the optically and geometrically thick layer of ice virga with $Z_{\mathrm{e}}$ up to $15 \mathrm{dBz}$ and Doppler velocities $<1 \mathrm{~m} \mathrm{~s}^{-1}$. This is in contrast to the relatively low $Z_{\mathrm{e}}$ of the snowfall in the afternoon $(<5 \mathrm{dBz})$ and larger Doppler velocities (up to $2 \mathrm{~m} \mathrm{~s}^{-1}$ ), indicating the presence of significantly fewer and somewhat larger particles (probably due to aggregation). Wind speed is decreasing from $>10 \mathrm{~m} \mathrm{~s}^{-1}$ down to negligible values in the afternoon (Fig. 4b), which could have assisted larger Doppler velocities favouring precipitation reaching the ground.

The hydrometeor layer after 18:00 UTC on 13 February contains precipitating ice crystals as indicated by the high radar $Z_{\mathrm{e}}$ and Doppler velocities of $\sim 1 \mathrm{~m} \mathrm{~s}^{-1}$ (Fig. 3b and c). The high ceilometer $\beta_{a}$ (Fig. 3a) could be caused either by the presence of liquid within this cloud or by specular reflection of horizontally oriented plate crystals (Hogan et al., 2003b; Thomas et al., 1990). The fact that $T_{\text {pyr }}$ is decreasing (Fig. 3d) supports the hypothesis of the ice dominance in this cloud system, which likely resulted in reduced emissivity. At 22:00 UTC, high $\beta_{a}$ within a geometrically thin layer and no significant MRR signal indicate the presence of a liquidcontaining cloud replaced shortly afterwards with ascending mid-level ice layers (Fig. 3a). With the appearance of this short-lived thin highly reflective layer, $T_{\mathrm{pyr}}$ increases again to $-20^{\circ} \mathrm{C}$, supporting the presence of liquid water with cloud emissivity probably approaching 1 , and counteracting the effect of the $1 \mathrm{~km}$ increase in the cloud base height (Fig. 3a and d).

Changing cloud properties exhibit a strong influence on $\mathrm{LW}_{\text {in }}$ (as high as $240-260 \mathrm{~W} \mathrm{~m}^{-2}$ during cloudy conditions; Fig. 4a). Near-surface air temperature is nearly constant at $-10^{\circ} \mathrm{C}$ during the entire day (Fig. 4c). During the snow-
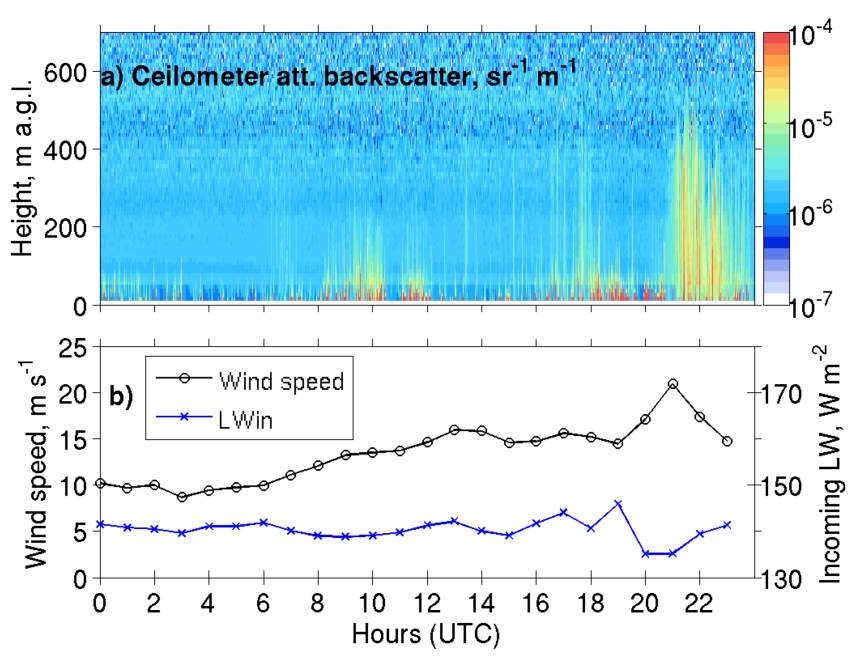

Figure 5. Cloud-free blowing snow event on 8 April 2013 (case 4): (a) $15 \mathrm{~s}$ ceilometer raw attenuated backscatter profiles, and (b) hourly mean wind speed and incoming LW flux.

fall event at 16:00 UTC, easterly winds up to $10 \mathrm{~m} \mathrm{~s}^{-1}$ slow down and change to southerly direction (Fig. 4b). Such wind behaviour demonstrates a transition from a synoptic regime (a storm under cyclonic influence) to a katabatic regime (southerly flow from the Antarctic interior with rather quiet wind speeds due to the mountain sheltering; Gorodetskaya et al., 2013). Small snow height variability throughout the day is associated with wind deposition/removal (in the absence of snowfall to the ground) and showing insignificant accumulation of snow after the snowfall event (Fig. 4d).

\subsubsection{Case 4: cloud-free sky blowing snow}

A special case on 8 April 2013 shows a strong blowing snow event occurring during cloudless conditions, which is a rare and extreme event at PE, where katabatic winds are usually rather weak being sheltered by the mountain range (Gorodetskaya et al., 2013; Thiery et al., 2012). The webcam movies during the daylight confirm clear-sky conditions and show a strong blowing snow event (see in the Supplement). In order to capture the details of the event, raw ceilometer $\beta_{a}$ profiles were investigated (Fig. 5a). The noise reduction and averaging used for cloud and precipitation recognition removes most of the clear-sky blowing snow layers and is not applied for this case.

Figure 5a shows snow particle presence in the lowest $100 \mathrm{~m}$ in the beginning of the day with the blowing snowlayer height increasing progressively during the day together with the increase in wind speeds (Fig. 5b). The largest $\beta_{a}$ values are observed near the surface diminishing with height until they reach low background magnitudes with high noise. The peak of the blowing snow-layer height up to $500 \mathrm{~m}$ occurs at 21:00-22:00 UTC when the hourly mean wind speed measured by the AWS increases up to $21 \mathrm{~m} \mathrm{~s}^{-1}$. Low 
$\mathrm{LW}_{\text {in }}$ values observed during this day $\left(140 \mathrm{~W} \mathrm{~m}^{-2}\right.$, Fig. $\left.5 \mathrm{~b}\right)$ are representative of a cold katabatic regime with clear-sky conditions (Gorodetskaya et al., 2013). The observed wind speeds by and large exceed the threshold needed for lifting snow from the ground up to significant heights according to observational and modelling studies (on average $\sim 8 \mathrm{~m} \mathrm{~s}^{-1}$, depending on snow properties) (Bintanja, 1998; Leonard et al., 2012).

The MRR detects no signal during this day, confirming that the blowing snow is limited to a shallow layer near the surface $(<500 \mathrm{~m}$ a.g.1.), while precipitation is expected to originate from much higher layers (Fig. 3b). Thus, the ceilometer signal strongest in the near-surface layers and decreasing with height, combined with low $\mathrm{LW}_{\text {in }}$ values, high near-surface wind speeds and absence of the MRR signal, can be used to distinguish cloud-free blowing snow events from snow falling from a cloud. Here we show only one example; further, analysis applied to longer time series and also to other ceilometer locations can produce valuable statistics on the clear-sky blowing snow heights. Observations at the South Pole using a micro-pulse lidar (Mahesh et al., 2003) showed an average blowing snow height of $\sim 400 \mathrm{~m}$ a.g.l., with half of the cases up to $200 \mathrm{~m}$ and occasional events reaching $>600 \mathrm{~m}$ (based on 11 months of measurements including summer and winter months). Using satellite-based lidar data, Palm et al. (2011) found an average depth of $120 \mathrm{~m}$ and a maximum of $1 \mathrm{~km}$ for all detected clear-sky blowing snow events over the entire Antarctic ice sheet.

\subsection{Statistics of cloud and precipitation properties}

\subsubsection{Combining ceilometer and radar profiles}

In addition to case studies, we provide a compilation of basic cloud and precipitation statistics derived from the remotesensing instruments based on the available measurement periods during 2010-2013 (14 months of cloud measurements mainly during summer through beginning of winter and 26 months of snowfall measurements including an entire year; see Table 1). First, ceilometer $\beta_{a}$ profiles were processed to exclude noise and clear-sky values using the PT algorithm described by Van Tricht et al. (2014). This allowed isolation of the profiles with cloud and/or precipitation at the original $15 \mathrm{~s}$ temporal resolution. Further, $\beta_{a}$ profiles were averaged over $1 \mathrm{~min}$ and collocated with MRR $Z_{\mathrm{e}}$ profiles. Finally, cloudy profiles with snowfall were identified using a condition $Z_{\mathrm{e}}>-8 \mathrm{dBz}$ at $400 \mathrm{~m}$ a.g.l. continuously during $10 \mathrm{~min}$. Cloudy profiles with liquid were detected using a threshold of $10^{-4} \mathrm{~s} \mathrm{r}^{-1} \mathrm{~m}^{-1}$ applied to $\beta_{a}$ profiles without snowfall. Thus, we identify the liquid-containing cloud layers which are not associated with snowfall to the ground, including those producing virga precipitation not reaching the surface.

Figure 6 shows the frequency by height for $Z_{\mathrm{e}}$ and $\beta_{a}$ demonstrating the typical cloud and precipitation signal in- tensities observed at PE and their distribution with height. Precipitation intensity near the surface $(400 \mathrm{~m}$ a.g.l.) is most frequent within $-5<Z_{\mathrm{e}}<10 \mathrm{dBz}$ (78\% of snowfall values at this range) narrowing upwards to $-2<Z_{\mathrm{e}}<8 \mathrm{dBz}$ at $2500 \mathrm{~m}$ a.g.l. (Fig. 6a). The tendency towards higher minimum $Z_{\mathrm{e}}$ values with height can be related to the decrease of MRR sensitivity with height (Maahn and Kollias, 2012). Precipitation of $1 \mathrm{~mm} \mathrm{~h}^{-1}$ is commonly used as a threshold between light and moderate precipitation intensities (Rasmussen et al., 1999). It corresponds to $13-25 \mathrm{dBz}$ according to the ensemble of $Z_{\mathrm{e}}-S$ relationships for dry snow (Table 5). Using the mean value $\left(Z_{\mathrm{e}}=17 \mathrm{dBz}\right)$ at $400 \mathrm{~m}$ a.g.l. as a threshold, $\mathrm{PE}$ is characterised overall by low intensity precipitation (97\% of total precipitation time) with rare occasional moderate intensity snowfalls (3\% of precipitation). Most of precipitation is confined within the first $2.5 \mathrm{~km}$ a.g.l., while moderate intensity precipitation is limited to $2 \mathrm{~km}$ a.g.l.

The frequency by height diagram for ceilometer $\beta_{a}$ was first constructed for all cloudy and precipitation profiles (Fig. 6b). The decrease of frequency of occurrence with height for the low $\beta_{a}$ values can be related, as for the radar, to the decreasing sensitivity of ceilometer with height leading to a possible underestimation of high-level optically thin ice clouds (Van Tricht et al., 2014). The most frequently observed backscatter signal is found within $10^{-5.5}<$ $\beta_{a}<10^{-4.5} \mathrm{~s} \mathrm{r}^{-1} \mathrm{~m}^{-1}$, observed from near the surface up to $3 \mathrm{~km}$ a.g.l. The nearest to the surface layers (below $500 \mathrm{ma.g.l.})$ are characterised by rather high backscatter $\left(10^{-5}<\beta_{a}<10^{-4} \mathrm{~s} \mathrm{r}^{-1} \mathrm{~m}^{-1}\right)$ and can be a signature of both clouds and precipitation to the ground. Excluding snowfall profiles from the analysis shows that these high $\beta_{a}$ values near the surface are related to snowfall, which can entirely attenuate the ceilometer signal near the surface (Fig. 6c). Cloudy profiles without snowfall show the highest frequency between $500 \mathrm{~m}$ and $3 \mathrm{~km}$ a.g.l. (Fig. 6c). Low $\beta_{a}$ values (< $10^{-5} \mathrm{~s} \mathrm{r}^{-1} \mathrm{~m}^{-1}$ ) dominate the layers below $1 \mathrm{~km}$ a.g.l. and are characteristic of ice layers extending down to the surface, which can be both cloud ice layers or light precipitation beyond the MRR sensitivity. Backscatter values larger than $10^{-4} \mathrm{~s} \mathrm{r}^{-1} \mathrm{~m}^{-1}$, which we can more certainly relate now to the liquid-containing cloud layers, are confined within the height interval between 1 and $3 \mathrm{~km}$ a.g.l. The near-surface layers below $1 \mathrm{~km}$ a.g.l. have a clear tendency towards low $\beta_{a}$ values more representative of ice cloud and/or precipitation layers.

As shown by Van Tricht et al. (2014), $80 \%$ of all clouds and precipitation layers at PE have base heights below $2 \mathrm{~km}$ a.g.l., while the majority $(78 \%)$ of the optically thick liquid-containing cloud layers have their bases between 1 and $3 \mathrm{~km}$ a.g.l. Combining these results with Fig. $6 \mathrm{c}$ points to a large vertical range of the ice layers, including both iceonly clouds and mixed-phase clouds. As demonstrated by the case studies (Sect. 4.1), mixed-phase clouds at PE with liquid-containing layers above $1 \mathrm{~km}$ can have ice layers extending close to the surface. At the same time, the ability 


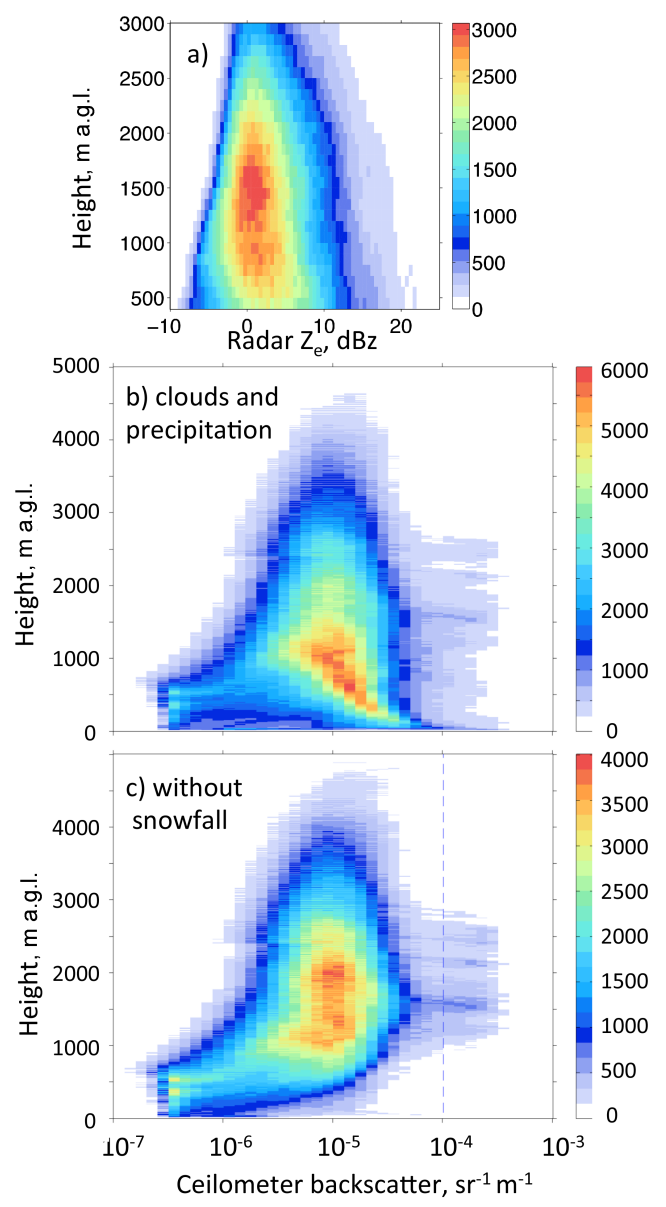

Figure 6. Number of occurrences by height on 1 min temporal scale for (a) MRR effective reflectivity $\left(Z_{\mathrm{e}}\right)$, (b) ceilometer backscatter for all cloudy/precipitation profiles, and (c) ceilometer backscatter for cloudy profiles excluding snowfall cases (see Sect. 4.2.1). Based on the measurement periods during 2010-2013 (14 months of cloud measurements mainly in summer-beginning of winter and 26 months of snowfall measurements including an entire year; see Table 1). The dashed vertical line indicates the threshold used for liquid-containing layers identification.

of the ceilometer to detect the vertical extent of the liquidcontaining clouds is limited due to the fast attenuation of the ceilometer signal by the liquid-containing layers (e.g. Platt et al., 1994). In addition, the rapid ceilometer signal attenuation makes it unsuitable for detection of multiple liquidcontaining layers.

\subsubsection{Cloud and snowfall occurrence frequency}

Using collocated $1 \mathrm{~min} \beta_{a}$ and $Z_{\mathrm{e}}$ values, we calculated hourly cloud occurrence frequency (COF), snowfall occurrence frequency (SOF) and liquid-containing cloud occurrence frequency (LCOF) distributions. Hourly COF is a metric generally used to express cloud cover based on point measurements in time (e.g. Town et al., 2007). Here it is ex-

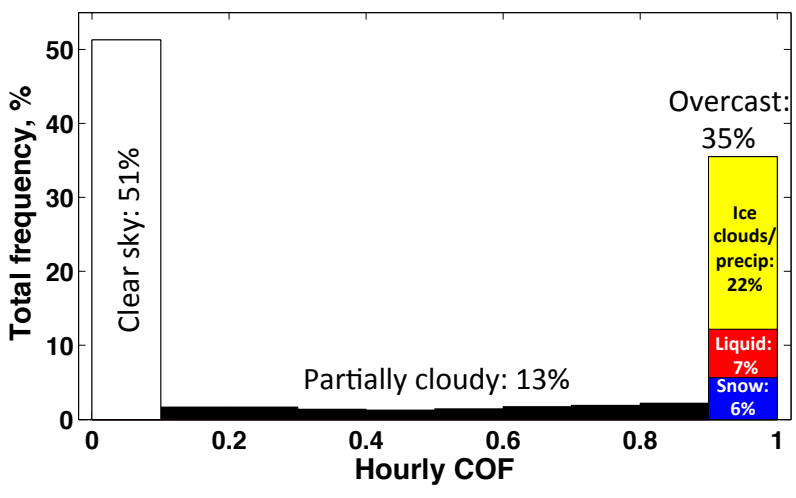

Figure 7. Total frequency relative to the measurement period (\%) of hourly mean cloud occurrence frequency (COF; unitless fraction from 0 to 1) for all clouds and precipitation. The column corresponding to $\mathrm{COF}>0.9$ shows also total frequency of liquid clouds (red), snowfall (blue), and ice clouds/precipitation not detected by MRR (yellow). Based on the measurement periods during 20102013 indicated in Table 1 (14 months mainly in summer-beginning of winter).

pressed as a unitless fraction (0-1) to distinguish from the COF distribution frequency given in \% (similarly for SOF and LCOF; see Fig. 7). Cloudiness at PE is strongly bimodal with the majority of the time being either clear sky or overcast (Fig. 7). Overcast conditions for all types of clouds and precipitation were observed $35 \%$ of the measurement period. Due to the presence of partial cloudiness, mean COF including all clouds and precipitation for the entire measurement period is 0.46 .

Further, the overcast conditions are divided among liquidcontaining clouds ( $7 \%$ of the total measurement period or $20 \%$ of the overcast periods), snowfall (6\% of the total period or $17 \%$ of the overcast) and ice clouds or weak precipitation not detected by MRR ( $22 \%$ of the total period or $63 \%$ of the overcast). Thus, while ice clouds occur most frequently, the liquid-containing clouds are also observed during a significant period of time. Low SOF, compared to cloudy periods, combined with precipitation intensity statistics (Fig. 6a), indicates once more the importance of occasional intense snowfall events. It should be noted that SOF was estimated only for the periods when cloud data were available (during summer-beginning of winter), thus excluding the winter snowfall measurements during 2012 (which are included in Fig. 6a). The frequency of liquid-containing clouds at PE is lower than found at various Arctic locations (32-56\%, Shupe, 2011), or at Greenland summit (from $10 \%$ in winter up to 40-60\% during summer; Shupe et al., 2013; Van Tricht et al., 2014).

\subsubsection{Snowfall and accumulation}

Further, we show the role of the snowfall-driven highaccumulation events in the local SMB. The PE site is 
characterised by high interannual variability in local SMB (230, 23, 227 and $52 \mathrm{~mm}$ w.e. during 2009, 2010, 2011 and 2012, respectively), which is in accordance with high interannual variability in a much larger region: yearly total accumulation averaged over the $180 \mathrm{~km}$ long stake line from PE to the coast is 606,157 , and $598 \mathrm{~mm}$ w.e. for 2009,2010 , and 2011, respectively. This stake line was installed within the GLACIOCLIM project (Agosta et al., 2012; Favier et al., 2013) and shows larger absolute values compared to PE as it includes coastal areas. The AWS measurements clearly show the anomalous accumulation observed over entire DML in 2009 and 2011 (Boening et al., 2012; Lenaerts et al., 2013; Gorodetskaya et al., 2014). SMB or net snow accumulation results from precipitation in the form of snow, which is then modified by surface sublimation/deposition, the erosion/deposition of snowdrift transport, the sublimation of drifting/blowing snow particles and melt (in the coastal areas of the ice sheet) (Van den Broeke et al., 2004; Frezzotti et al., 2013). While precipitation is the major positive component of the SMB, it is difficult to disentangle the contribution of precipitation from continuous wind-driven snow deposition and erosion. Here, we use radar-derived snowfall rates collocated with snow height changes from the AWS sonic snow height ranger in order to estimate the contribution of snowfall to the local SMB and attempt to distinguish accumulation due to snowfall from accumulation due to the wind deposition.

We analyse in detail daily mean snow height changes and snowfall rates during 2 years (2011-2012), which are characterised by very different yearly snow accumulation (Fig. 8). Each year is punctuated by several occasional highaccumulation events, defined as days with accumulation $>$ $10 \mathrm{~mm}$ w.e. day $^{-1}$, the 95 th percentile based on 2009-2012 daily mean positive accumulation values (indicated with blue circles in Fig. 8). In total, 15 high-accumulation events were found during this 2-year period. While the 2 years did not differ much in terms of the amount of high-accumulation events, the magnitude of accumulation per event was much higher during 2011.

Using radar measurements, we attributed all of these highaccumulation events to snowfall of various intensity (blue diamonds in Fig. 8). The three most intense snowfalls, leading to the largest daily snow accumulation, occurred during 2011 (14-17 February, 16-17 December and 19-20 December), and were associated with exceptional moisture transport towards East Antarctica organised into so-called atmospheric rivers (Gorodetskaya et al., 2014). During the winter 2011, the attribution of exceptionally high-accumulation events to measured snowfall rates was unfortunately not possible due to the radar-measurements gap; however, strong moisture fluxes into PE found using ERA-Interim data during these events indicate the potential contribution of snowfall. Daily accumulation values $>10 \mathrm{~mm}$ w.e. day $^{-1}$ are significantly correlated with snowfall rates $(r=0.6$ at $99 \%$ significance level), while correlation is low for the entire time

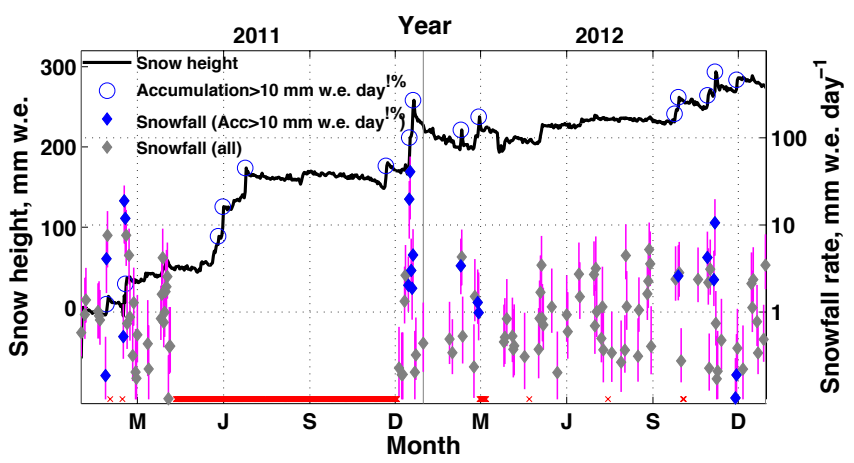

Figure 8. Daily snow height (with respect to 1 January 2011) and snowfall rate $(S)$ during 2011-2012. High-accumulation events $\left(>10 \mathrm{~mm}\right.$ w.e. day $^{-1}$ ) are marked with blue circles and corresponding snowfall events - with blue diamonds. Grey diamonds show all other snowfall events. Vertical magenta lines show uncertainty in $S$ for a range of $Z_{\mathrm{e}}-S$ relationships for dry snow (Table 5; Sect. 3.2). Horizontal red bar and crosses at bottom indicate gaps in snowfall measurements. Letters on $x$ axis mark the first day of each month.

series. Despite the differences in snowfall intensity and uncertainties in $Z_{\mathrm{e}}-S$ relationships, radar measurements allow for the direct association of high snow-accumulation events with snowfall. The occasional nature of snowfalls and associated stepwise snow height changes, necessitate fine temporal resolution measurements demonstrated both by MRR (averaged to $1 \mathrm{~min})$ and an acoustic snow height ranger $(1 \mathrm{~h})$.

At the same time, small and medium accumulation events could be both due to snowfall and wind-driven deposition (Fig. 8). Also, some intense snowfall events result in zero net snow accumulation due to the snow removal by strong winds under cyclonic conditions. During the winter of 2012, for example, snowfall was observed rather frequently, resulting in no significant snow height changes (Fig. 8). In the next subsection we discuss the importance of other SMB components in addition to snowfall in determining the net snow accumulation.

\subsubsection{Surface mass balance components}

Snowfall measurements were available almost continuously during 2012 (Fig. 8), allowing to compare radar-derived snowfall rates to the other SMB components. At PE, snow height changes $(\mathrm{SH})$ are measured by the AWS sonic height sensor and are converted to water equivalent values using local snow density measurements (see Sect. 3.1). SH represents local SMB and results from the following components: snowfall $(S)$, surface sublimation $\left(\mathrm{SU}_{\mathrm{s}}\right)$, drifting snow sublimation $\left(\mathrm{SU}_{\mathrm{ds}}\right)$, and wind-driven erosion/deposition of the drifting snow $\left(\mathrm{ER}_{\mathrm{ds}}\right) . S$ is the principal positive $\mathrm{SMB}$ term and is derived from MRR $Z_{\mathrm{e}}$ measurements at $400 \mathrm{~m}$ a.g.l. An error estimate for snowfall rates from radar reflectivities is difficult. Using persistently minimum and maximum $S$ values from the ensemble of $Z_{\mathrm{e}}-S$ relations given in Table 5 (see 
also Maahn et al., 2014) results in an error range of -50 to $132 \%$, which is certainly very pessimistic. As from event to event one or another $Z_{\mathrm{e}}-S$ relation may fit best to reality, we used a Monte Carlo approach: this method is based on equally random selection of the $Z_{\mathrm{e}}-S$ relationship for each precipitation event from the entire ensemble. The total yearly $S$ is then calculated as the mean of the Monte Carlo normal distribution, while the uncertainty is represented by two standard deviations covering $95 \%$ of the distribution. The true error in $S$ might be much larger due to several other sources of uncertainty in addition to $Z_{\mathrm{e}}-S$ relationships. Common sources of additional error in the $S$ estimate are for example: radar calibration and radar sensitivity limitations (Maahn and Kollias, 2012; Maahn et al., 2014), representativeness of our selected $Z_{\mathrm{e}}-S$ ensemble for the observed snowfall, changes in snowfall properties (e.g. sublimation) between the lowest radar range gate and the surface, or advection effects due to strong horizontal winds. Therefore, we use the radarretrieved $S$ values to attribute the measured SMB to snowfall while being aware of the potentially large uncertainties of the $S$ estimates.

The other SMB components are estimated as following. $\mathrm{SU}_{\mathrm{s}}$ is obtained from the surface latent heat flux estimated using bulk flux-profile relationships (Van den Broeke et al., 2004), whereas $\mathrm{SU}_{\mathrm{ds}}$ is calculated as the mean of two parameterisations, described by Bintanja (1998) and Déry and Yau (2001). Detailed description of $\mathrm{SU}_{\mathrm{s}}$ and $\mathrm{SU}_{\mathrm{ds}}$ estimates is given by Thiery et al. (2012). The uncertainty in $\mathrm{SU}_{\mathrm{s}}$ is calculated based on the AWS instrument accuracy, while $\mathrm{SU}_{\mathrm{ds}}$ uncertainty is determined by differences in the two parameterisations. $\mathrm{ER}_{\mathrm{ds}}$ is calculated as a residual term: $\mathrm{ER}_{\mathrm{ds}}=$ $S-\mathrm{SU}_{\mathrm{ds}}-\mathrm{SU}_{\mathrm{s}}-\mathrm{SH}$, with combined standard uncertainty based on the uncertainties of all input components.

Radar-derived snowfall rate summed over the year 2012 is $110 \pm 20 \mathrm{~mm}$ w.e. $\mathrm{yr}^{-1}$. During this time, $\mathrm{SU}_{\mathrm{s}}$ and $\mathrm{SU}_{\mathrm{ds}}$ removed $15 \pm 7$ and $10 \pm 2 \mathrm{~mm}$ w.e. $\mathrm{yr}^{-1}$, respectively, together representing $23 \%$ of precipitation input at the site. Given the measured SH of $52 \pm 3 \mathrm{~mm}$ w.e. $\mathrm{yr}^{-1}$, we obtain $\mathrm{ER}_{\mathrm{ds}}$ of $33 \pm 21 \mathrm{~mm}$ w.e. $\mathrm{yr}^{-1}$, which corresponds to $30 \%$ of the precipitation input. This $\mathrm{ER}_{\mathrm{ds}}$ value represents the total snow erosion by the wind over the year.

Figure 9 shows cumulative daily SMB components during 2012. Several extreme SH peaks can be attributed to intense snowfall events (e.g. beginning of May and July, end of September) with significant snow removal in-between the events (e.g. during May, July-September, October). A substantial fraction of this snow removal is due to $\mathrm{SU}_{\mathrm{s}}$ and $\mathrm{SU}_{\mathrm{ds}}$ components, which are relatively small on a daily basis (thus closely following the $S$ curve with much stronger changes), but persistent throughout the year. Removal by $\mathrm{SU}_{\mathrm{s}}$ also exhibits a seasonal cycle being larger during austral summer (November-February).

Removal by the wind $\left(\mathrm{ER}_{\mathrm{ds}}\right)$ shows a greater impact compared to sublimation terms with much higher temporal variability. The negative values of SH during January-April (rel-

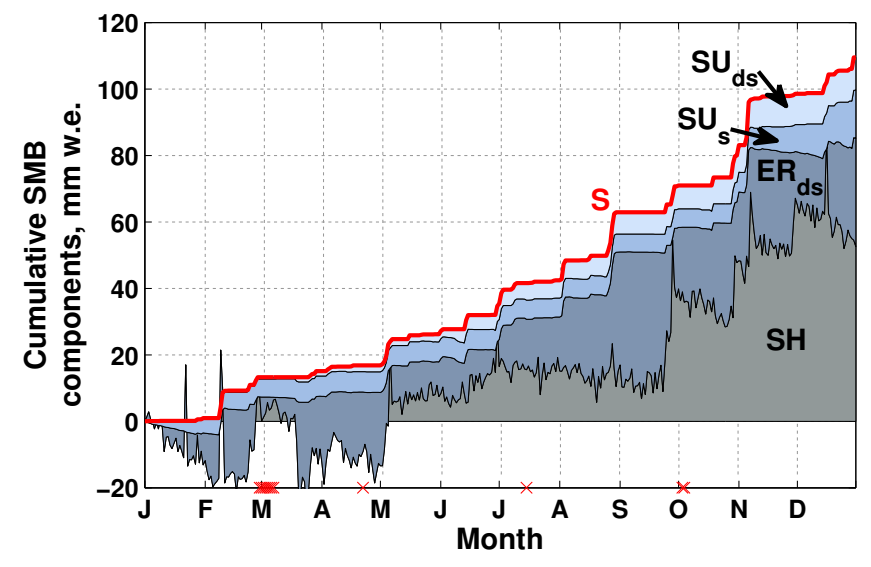

Figure 9. Cumulative daily surface mass balance (SMB) components during 2012: snowfall $(S)$, surface sublimation $\left(\mathrm{SU}_{\mathrm{S}}\right)$, drifting snow sublimation $\left(\mathrm{SU}_{\mathrm{ds}}\right)$, drifting snow erosion $\left(\mathrm{ER}_{\mathrm{ds}}\right)$, and measured snow height changes since 1 January 2012 (SH) (Sect. 4.2.4). $\mathrm{SU}_{\mathrm{s}}$ and $\mathrm{SU}_{\mathrm{ds}}$ are plotted as ablation terms. $\mathrm{ER}_{\mathrm{ds}}$ is calculated and plotted as a residual term: $\mathrm{ER}_{\mathrm{ds}}=S-\mathrm{SU}_{\mathrm{ds}}-\mathrm{SU}_{\mathrm{s}}-\mathrm{SH}$. Red crosses at the bottom indicate days of missing MRR data. Letters on $x$ axis mark the first day of each month.

ative to 1 January 2012) can be explained by both high $\mathrm{SU}_{\mathrm{s}}$ during summer months together with high $\mathrm{ER}_{\mathrm{ds}}$ term, removing the snow accumulated during the previous year. Both $S$ and $\mathrm{ER}_{\mathrm{ds}}$ strongly contributed to the large $\mathrm{SH}$ peak in the beginning of February, followed by a significant snow removal by $\mathrm{ER}_{\mathrm{ds}}$ and $\mathrm{SU}_{\mathrm{s}}$. Later during the year, $\mathrm{ER}_{\mathrm{ds}}$ also contributed to snow accumulation during some snowfall events (for instance, in early May and end of September), while some days with large $S$ show negligible or even slightly negative SH changes (for example, beginning and end of August). The latter phenomenon was illustrated by case 2 (Sect. 4.1.3), when rather long and intense snowfall (Fig. 3b) accompanied by high wind speeds (Fig. 4b) resulted in zero net snow accumulation (Fig. 4d). Thus, our results highlight the important contribution of both snowfall and wind-driven erosion/deposition to the local SMB.

\section{Conclusions and Outlook}

In this paper we present a new cloud-precipitationmeteorological observatory established in the escarpment zone of eastern DML, East Antarctica. Cloud and precipitation properties at high vertical and temporal resolution are derived from a set of ground-based remote-sensing instruments $(910 \mathrm{~nm}$ ceilometer, $8-14 \mu \mathrm{m}$ radiation pyrometer and $24 \mathrm{GHz}$ vertically profiling precipitation radar). These are combined with automatic weather station measurements of near-surface meteorology and radiative fluxes, as well as local snow height changes.

The paper demonstrates the value of this set of instruments via detailed case studies and presents basic cloud and 
precipitation properties based on the available measurement periods during 2010-2013. Case studies show the ability of the observatory to capture complex and constantly evolving cloud and precipitation properties, as well as to measure intense wind-driven blowing snow events. In particular, we have demonstrated the potential of the observatory to be used for investigating the following relationships:

- distinguish between ice clouds (including weak precipitation), virga (precipitation not reaching the surface), liquid-containing clouds and snowfall;

- study the effect of changing cloud base heights and temperatures on surface radiative fluxes;

- assess the vertical extent and radiative forcing of thin ice clouds;

- assure that radar-derived snowfall (limited to 400 m a.g.1.) is observed all the way to the surface;

- identify intense (>10 ma.g.l.) wind-driven blowing snow events during cloud-free conditions;

- distinguish snow accumulation due to snowfall from wind-driven deposition;

- quantify the SMB components and study their relation to meteorological conditions.

Statistical analysis using ceilometer and MRR measurements during austral summer to beginning of winter 20102013 reveals cloud and precipitation properties, many of which are derived for the first time over the Antarctic ice sheet. Ice cloud layers and weak precipitation are most frequently found from near the surface up to $3-3.5 \mathrm{~km}$ a.g.l., while the lowest observed liquid-containing cloud layers are confined to $1-3 \mathrm{~km}$ a.g.l.

Clouds at PE show a clear bimodal distribution with either clear sky or overcast most of the time. While ice-only clouds (including virga) occur most frequently (63\% of cloudy periods), liquid-containing clouds are also observed during a significant period of time ( $20 \%$ of all cloudy overcast cases). Snowfall rates derived from radar measurements show high frequency of low intensity precipitation with rare occasional moderate intensity snowfalls of $>1 \mathrm{~mm}$ w.e. $\mathrm{h}^{-1}$ (observed $3 \%$ of the total precipitation period).

Another long-standing question, which can be addressed using the observatory data, is attribution of accumulation to snowfall in contrast to the wind-driven deposition. Despite the naturally large uncertainty in the derived snowfall intensity due to the large range of possible $Z_{\mathrm{e}}-S$ relationships, as well as limitation to vertical profiling, MRR measurements give an opportunity to obtain high-resolution estimates of snowfall rate and relate them to the snow accumulation on the ground. High temporal resolution of radar measurements together with typically large-scale and occasional nature of synoptic-driven precipitation allows capture of all major precipitation events contributing to the local SMB. Large local accumulation events $\left(>10 \mathrm{~mm}\right.$ w.e. day $^{-1}$ ), responsible for the majority of the total annual SMB, are all attributed to occasional snowfall of various intensity (during the radarmeasurements period). It is extremely important to capture these few strong events and missing them can lead to a large underestimation of the total yearly snow accumulation.

In contrast to the large accumulation events, medium to low accumulation occur both due to snowfall and winddriven deposition. Also not every snowfall results in significant snow accumulation, and wind erosion (together with sublimation) can entirely remove locally precipitated snow mass. Combining radar-derived snowfall rates during 2012 with sublimation estimates based on the AWS measurements, allowed us to isolate the wind-driven erosion term and compare it to other SMB components. The radar-derived snowfall rate summed over the year 2012 is $110 \pm 20 \mathrm{~mm}$ w.e. $\mathrm{yr}^{-1}$. Surface and drifting snow sublimation removed $15 \pm 7$ and $10 \pm 2 \mathrm{~mm}$ w.e. $\mathrm{yr}^{-1}$, respectively, together representing $23 \%$ of the snowfall input during this year. Given the measured yearly SMB of $52 \mathrm{~mm}$ w.e. $\mathrm{yr}^{-1}$ for 2012 , we obtained that $33 \pm 21 \mathrm{~mm}$ w.e. $\mathrm{yr}^{-1}$ (30\% of the snowfall input) was removed by wind-driven snow erosion. Attribution of accumulation to snowfall, which can be achieved using precipitation radar measurements, is important not only for understanding the hydrological cycle processes and mechanisms behind surface mass balance but also for paleoclimate record interpretation (Masson-Delmotte et al., 2008; Schlosser et al., 2010).

Application of the observatory extends beyond clouds and precipitation, and can be used to capture intense winddriven blowing snow events (in the absence of snowfall from clouds) up to several hundred meters above the ground, associated with strong near-surface winds. Measurements from the ceilometer installed at PE and also lidars and ceilometers found at other locations around Antarctica (e.g. Mahesh et al., 2003) can be used for evaluation of the satellite-derived large-scale blowing snow events (Palm et al., 2011).

The goal of the observatory is to evaluate clouds and precipitation simulated by climate models allowing both a detailed look into processes and statistical comparisons. It can also be used in synergy with satellite cloud and precipitation data. Collocating profiles from ground-based and satellite lidars can offer better representation of the cloud vertical structure. Similarly, collocation of MRR precipitation measurements with satellite-based radar provides additional information on precipitation occurrence and properties close to the surface offering a solution to the disturbance of satellite radars due to ground clutter (Maahn et al., 2014). In general, the robust instrumentation operational at the PE station (ceilometer, radar, infrared thermometer and weather station with snow height meter) represents a promising tool to improve insight in cloud and precipitation processes in Antarctica, and can be easily deployed at other Antarctic stations. 


\section{The Supplement related to this article is available online at doi:10.5194/tc-9-285-2015-supplement.}

Acknowledgements. This project has been successful thanks to the continuous support of many people, companies and institutions. We are grateful to the Belgian Federal Science Policy (BELSPO) for the financial support of the HYDRANT project (EA/01/04AB). We thank International Polar Foundation (IPF) and all staff at Princess Elisabeth base for providing the infrastructure, technical and logistical support, and particularly Erik Verhagen and Karel Moerman (IPF) for help with on-site instrument maintenance. Special thanks for continuous technical support of the KU Leuven engineers Jos Meersmans and Valentijn Tuts, and all companies who provided the remote-sensing instruments and technical support - Vaisala (Finland), Heitronics/MeraBenelux (Germany/the Netherlands), Metek (Germany), and Mobotix (Germany). Many thanks to Johan Boon and Hilde Vandenhoeck (KU Leuven) for computer and website support. We are grateful to Michiel van den Broeke, Carleen Reijmer and Wim Boot (Institute for Marine and Atmospheric research Utrecht, the Netherlands) for scientific discussions, the AWS development, support and raw data processing. We are grateful to Roland Meister (Institute for Snow and Avalanche Research - SLF, Switzerland) for providing the equipment and training for snow pit measurements. We thank the French Glacioclim-SAMBA project (http://www-lgge.ujf-grenoble.fr/ServiceObs/SiteWebAntarc/ glacioclim-samba.php), Christophe Genthon and Vincent Favier (Laboratoire de Glaciologie et Géophysique de l'Environnement, France) and IPF for providing the PE-coast stake-line snow measurements. We thank colleagues from the Regional Climate Studies group at KU Leuven for their support and feedback. I. V. Gorodetskaya was funded by the BELSPO grants EA/01/04A and EA/01/04B; A. Mangold was funded by BELSPO grants EA/34/1A and EA/34/1B; M. Maahn was supported by the project ADMIRARI II of the German Research Association (DFG) under research grant no. LO901/5-1; K. Van Trich was supported by the Belgian Research Foundation Flanders (FWO) PhD fellowship. The University of Cologne contributions were partly performed at the Hans-Ertel Centre for Weather Research - Climate Monitoring Branch funded by the Federal Ministry of Transport, Building and Urban Development (BMVBS) of Germany and supported by a postdoc fellowship of the German Academic Exchange Service (DAAD).

Edited by: M. Schneebeli

\section{References}

Agosta, C., Favier, V., Genthon, C., Gallée, H., Krinner, G., Lenaerts, J. T. M., and van den Broeke, M. R.: A 40-year accumulation dataset for Adelie Land, Antarctica and its application for model validation, Clim. Dynam., 38, 75-86, doi:10.1007/s00382-011-1103-4, 2012.

American Meteorological Society: Virga, Glossary of Meteorology, available at: http://glossary.ametsoc.org/wiki/Virga, last access: 25 October, 2014.
Amundsen, R.: The South pole; an account of the Norwegian Antarctic expedition in the "Fram" 1910-1912, Volume I + II, available via Project Gutenberg at: https://archive.org/details/ thesouthpoleanac04229gut (last access: 5 February 2015), 1912.

Arctowski, H.: Aperçu des resultats meteorologiques de 1'hivernage antarctique de la "Belgica", Ann. Met. Observ. Roy. Belg. (Bruxelles), National Oceanic and Atmospheric Administration and the Climate Database Modernization Program, National Climate Data Center, Beltsville, MD, USA, 267, available at: http://docs.lib.noaa.gov/rescue/IPY/ipy_004_ pdf/Qc9949a731904.pdf (last access: 4 February 2015), 1904.

Averianov, V. G.: Glyatsio-klimatologiya Antarktidy [Glacioclimatology of Antarctic], Gidrometeoizdat, Leningrad, 197 pp., 1990.

Bennartz, R., Shupe, M. D., Turner, D. D., Walden, V. P., Steffen, K., Cox, C. J., Kulie, M. S., Miller, N. B., and Pettersen, C.: July 2012 Greenland melt extent enhanced by low-level liquid clouds, Nature, 496, 83-86, doi:10.1038/nature12002, 2013.

Berque, J., Lubin, D., and Somerville, R. C. J.: Transect method for Antarctic cloud property retrieval using AVHRR data, Int. J. Remote Sens., 32, 2887-2903, 2011.

Bintanja, R.: The contribution of snowdrift sublimation to the surface mass balance of Antarctica, Ann. Glaciol., 27, 251-259, 1998.

Bintanja, R. and Van den Broeke, M. R.: The influence of clouds on the radiation budget of ice and snow surfaces in Antarctica and Greenland in summer, Int. J. Climatol., 16, 1281-1296, 1996.

Boening, C., Lebsock, M., Landerer, F., and Stephens, G.: Snowfalldriven mass change on the East Antarctic ice sheet, Geophys. Res. Lett., 39, L21501, doi:10.1029/2012GL053316, 2012.

Bromwich, D. H., Nicolas, J. P., Hines, K. M., Kay, J. E., Key, E. L., Lazzara, M. A., Lubin, D., McFarquhar, G. M., Gorodetskaya, I. V., Grosvenor, D. P., Lachlan-Cope, T., and Van Lipzig, N. P. M.: Tropospheric clouds in Antarctica, Rev. Geophys., 50, RG1004, doi:10.1029/2011RG000363, 2012.

Bryazgin, N. N.: Atmosfernye osadki v Antarktide i ih mnogoletnyaa izmenchivost' [Atmospheric precipitation in Antarctica and its inter-annual variability], Meteorol. Issled. v Antarktike - Part I., Leningrad: Gidrometeoizdat, 30-34, 1990.

Cesana, G., Kay, J. E., Chepfer, H., English, J. M., and de Boer, G.: Ubiquitous low-level liquid-containing Arctic clouds: New observations and climate model constraints from CALIPSO-GOCCP, Geophys. Res. Lett., 39, L20804, doi:10.1029/2012GL053385, 2012.

Colle, B. A., Stark, D., and Yuter, S. E.: Surface Microphysical Observations Within East Coast Winter Storms on Long Island, NY, Mon. Weather Rev., 142, 3126-3146, doi:10.1175/MWR-D-14$00035.1,2014$.

Das, I., Bell, R. E., Scambos, T. A., Wolovick, M., Creyts, T. T., Studinger, M., Frearson, N., Nicolas, J. P., Lenaerts, J. T. M., and Van den Broeke, M. R.: Influence of persistent wind scour on the surface mass balance of Antarctica, Nat. Geosci., 6, 367-371, doi:10.1038/ngeo1766, 2013.

de Gerlache, A.: Quinze mois dans l'Antarctique, Imprimerie Scientifique Ch. Bulens, Editeur (Bruxelles), 304pp, available at: https://archive.org/details/voyagedelabelgi00unkngoog (last access: 5 February 2015), 1902.

Dee, D. P., Uppala, S. M., Simmons, A. J., Berrisford, P., Poli, P., Kobayashi, S., Andrae, U., Balmaseda, M. A., Balsamo, G., 
Bauer, P., Bechtold, P., Beljaars, A. C. M., van de Berg, L., Bidlot, J., Bormann, N., Delsol, C., Dragani, R., Fuentes, M., Geer, A. J., Haimberger, L., Healy, S. B., Hersbach, H., Hólm, E. V., Isaksen, L., Kå llberg, P., Köhler, M., Matricardi, M., McNally, A. P., Monge-Sanz, B. M., Morcrette, J.-J., Park, B.-K., Peubey, C., de Rosnay, P., Tavolato, C., Thépaut, J.-N., and Vitart, F.: The ERA-Interim reanalysis: configuration and performance of the data assimilation system, Q. J. Roy. Meteor. Soc., 137, 553-597, doi:10.1002/qj.828, 2011

Del Guasta, M., Morandi, M., Stefanutti, L., Brechet, J., and Piquad, J.: One year of cloud lidar data from Dumont d'Urville (Antarctica): 1. General overview of geometrical and optical properties, J. Geophys. Res., 98, 18575-18587, doi:10.1029/93JD01476, 1993.

Déry, S. J. and Yau, M. K.: Simulation of blowing snow in the Canadian Arctic using a double-moment model, Bound.-Lay. Meteorol., 99, 297-316, doi:10.1023/A:1018965008049, 2001.

Devasthale, A., Tjernström, M., Karlsson, K.-G., Thomas, M. A., Jones, C., Sedlar, J., and Omar, A. H.: The vertical distribution of thin features over the Arctic analysed from CALIPSO observations, Tellus B, 63, 77-85, doi:10.1111/j.1600-0889.2010.00516.x, 2011.

Favier, V., Agosta, C., Parouty, S., Durand, G., Delaygue, G., Gallée, H., Drouet, A.-S., Trouvilliez, A., and Krinner, G.: An updated and quality controlled surface mass balance dataset for Antarctica, The Cryosphere, 7, 583-597, doi:10.5194/tc-7-5832013, 2013.

Field, P. R., Hogan, R. J., Brown, P. R. A., Illingworth, A. J., Choularton, T. W., and Cotton, R. J.: Parametrization of iceparticle size distributions for mid-latitude stratiform cloud, Q. J. Roy. Meteor. Soc., 131, 1997-2017, doi:10.1256/qj.04.134, 2005.

Frezzotti, M., Urbini, S., Proposito, M., Scarchilli, C., and Gandolfi, S.: Spatial and temporal variability of surface mass balance near Talos Dome, East Antarctica, J. Geophys. Res., 112, F02032, doi:10.1029/2006JF000638, 2007.

Frezzotti, M., Scarchilli, C., Becagli, S., Proposito, M., and Urbini, S.: A synthesis of the Antarctic surface mass balance during the last 800 yr, The Cryosphere, 7, 303-319, doi:10.5194/tc-7-3032013, 2013.

Gallée, H. and Gorodetskaya, I. V.: Validation of a limited area model over Dome C, Antarctic Plateau, during winter, Clim. Dynam., 34, 61-72, doi:10.1007/s00382-008-0499-y, 2008.

Gallée, H., Guyomarch, G., and Brun, E.: Impact of snow drift on the antarctic ice sheet surface mass balance: possible sensitivity to snow-surface properties, Bound.-Lay. Meteorol., 99, 1-19, 2001

Gallée, H., Peyaud, V., and Goodwin, I.: Simulation of the net snow accumulation along the Wilkes Land transect, Antarctica, with a regional climate model, Ann. Glaciol., 41, 17-22, doi:10.3189/172756405781813230, 2005.

Gay, M., Fily, M., Genthon, C., Frezzotti, M., Oerter, H., and Winther, J.-G.: Snow grain-size measurements in Antarctica, J. Glaciol., 48, 527-535, doi:10.3189/172756502781831016, 2002.

Gayet, J.-F., Mioche, G., Dörnbrack, A., Ehrlich, A., Lampert, A., and Wendisch, M.: Microphysical and optical properties of Arctic mixed-phase clouds. The 9 April 2007 case study., At- mos. Chem. Phys., 9, 6581-6595, doi:10.5194/acp-9-6581-2009, 2009.

Girard, E. and Blanchet, J.-P.: Simulation of Arctic diamond dust, ice fog, and thin stratus using an explicit aerosol-cloud-radiation model, J. Atmos. Sci., 58, 1199-1221, doi:10.1175/15200469(2001)058<1199:SOADDI>2.0.CO;2, 2001.

Gorodetskaya, I. V., Van Lipzig, N. P. M., Van den Broeke, M. R., Mangold, A., Boot, W., and Reijmer, C. H.: Meteorological regimes and accumulation patterns at Utsteinen, Dronning Maud Land, East Antarctica: Analysis of two contrasting years, J. Geophys. Res.-Atmos., 118, 1700-1715, doi:10.1002/jgrd.50177, 2013.

Gorodetskaya, I. V., Tsukernik, M., Claes, K., Ralph, M. F., Neff, W. D., and Van Lipzig, N. P. M.: The role of atmospheric rivers in anomalous snow accumulation in East Antarctica, Geophys. Res. Lett., 41, 6199-6206, doi:10.1002/2014GL060881, 2014.

Gregory, J. M. and Huybrechts, P.: Ice-sheet contributions to future sea-level change., Philos. T. Roy. Soc. A, 364, 1709-31, doi:10.1098/rsta.2006.1796, 2006.

Grenier, P., Blanchet, J. P., and Muñoz-Alpizar, R.: Study of polar thin ice clouds and aerosols seen by CloudSat and CALIPSO during midwinter 2007, J. Geophys. Res.-Atmos., 114, D09201, doi:10.1029/2008JD010927, 2009.

Groot Zwaaftink, C. D., Cagnati, A., Crepaz, A., Fierz, C., Macelloni, G., Valt, M., and Lehning, M.: Event-driven deposition of snow on the Antarctic Plateau: analyzing field measurements with SNOWPACK, The Cryosphere, 7, 333-347, doi:10.5194/tc7-333-2013, 2013.

Hahn, C. J. and Warren, S. G.: Cloud Climatology for Land Stations Worldwide, 1971-1996., Tech. rep., NDP- 026D, Carbon Dioxide Information Analysis Center, Oak Ridge National Laboratory, Oak Ridge, TN, USA, doi:10.3334/CDIAC/cli.ndp026d, 2003.

Henderson, D. S., L'Ecuyer, T., Stephens, G., Partain, P., and Sekiguchi, M.: A Multisensor Perspective on the Radiative Impacts of Clouds and Aerosols, J. Appl. Meteorol. Climatol., 52, 853-871, doi:10.1175/JAMC-D-12-025.1, 2013.

Hogan, R. J., Francis, P. N., Flentje, H., Illingworth, A. J., Quante, M., and Pelon, J.: Characteristics of mixed phase clouds. Part I: Lidar, radar and aircraft observations from CLARE '98, Q. J. Roy. Meteor. Soc, 129, 2089-2116., doi:10.1256/rj.01.208, 2003a.

Hogan, R. J., Illingworth, A. J., O'Connor, E. J., and PoiaresBaptista, J. P. V.: Characteristics of mixed-phase clouds. Part II: A climatology from ground-based lidar, Q. J. Roy. Meteor. Soc., 129, 2117-2134, doi:10.1256/qj.01.209, 2003b.

IPCC: Climate Change 2013: The Physical Science Basis. Contribution of Working Group I to the Fifth Assessment Report of the Intergovernmental Panel on Climate Change., available at: http://www.climatechange2013.org/(last access: 25 October 2014), 2013.

Kneifel, S., Maahn, M., Peters, G., and Simmer, C.: Observation of snowfall with a low-power FM-CW K-band radar (Micro Rain Radar), Meteorol. Atmos. Phys., 113, 75-87, doi:10.1007/s00703-011-0142-z, 2011.

Konishi, H., Wada, M., and Endoh, T.: Seasonal variations of cloud and precipitation at Syowa station, Antarctica, Ann. Glaciol., 27, 597-602, 1998. 
Krinner, G., Magand, O., Simmonds, I., Genthon, C., and Dufresne, J. L.: Simulated Antarctic precipitation and surface mass balance at the end of the twentieth and twenty-first centuries, Clim. Dynam., 28, 215-230, doi:10.1007/s00382-006-0177-x, 2007.

Kuipers Munneke, P., Reijmer, C. H., and van den Broeke, M. R.: Assessing the retrieval of cloud properties from radiation measurements over snow and ice, Int. J. Climatol., 31, 756-769, doi:10.1002/joc.2114, 2011.

Kulie, M. S. and Bennartz, R.: Utilizing Spaceborne Radars to Retrieve Dry Snowfall, J. Appl. Meteorol. Climatol., 48, 25642580, doi:10.1175/2009JAMC2193.1, 2009.

Lachlan-Cope, T.: Antarctic clouds, Polar Research, 29, 150-158, doi:10.1111/j.1751-8369.2010.00148.x, 2010.

Lachlan-Cope, T., Ladkin, R., Turner, J., and Davison, P.: Observations of cloud and precipitation particles on the Avery Plateau , Antarctic Peninsula, Antarct. Sci., 13, 339-348, doi:10.1017/S0954102001000475, 2001.

Lampert, A., Ehrlich, A., Dörnbrack, A., Jourdan, O., Gayet, J.F., Mioche, G., Shcherbakov, V., Ritter, C., and Wendisch, M.: Microphysical and radiative characterization of a subvisible midlevel Arctic ice cloud by airborne observations - a case study, Atmos. Chem. Phys., 9, 2647-2661, doi:10.5194/acp-9-26472009, 2009.

Lawson, P. R., Baker, B. A., Zmarzly, P., O’Connor, D., Qixu, M., Gayet, J.-F., and Shcherbakov, V.: Microphysical and Optical Properties of Atmospheric Ice Crystals at, J. Appl. Meteorol. Climatol., 45, 1505-1524, 2006.

Lazzara, M. A., Keller, L. M., Stearns, C. R., Thom, J. E., and Weidner, G. A.: Antarctic Satellite Meteorology: Applications for Weather Forecasting, Mon. Weather Rev., 131, 371-383, doi:10.1175/1520-0493(2003)131<0371:ASMAFW>2.0.CO;2, 2003.

Lenaerts, J. T., Van Den Broeke, M. R., Scarchilli, C., and Agosta, C.: Impact of model resolution on simulated wind, drifting snow and surface mass balance in Terre Adélie, East Antarctica, J. Glaciol., 58, 821-829, doi:10.3189/2012JoG12J020, 2012a.

Lenaerts, J. T. M., van den Broeke, M. R., van de Berg, W. J., van Meijgaard, E., and Kuipers Munneke, P.: A new, high-resolution surface mass balance map of Antarctica (1979-2010) based on regional atmospheric climate modeling, Geophys. Res. Lett., 39, L04501, doi:10.1029/2011GL050713, 2012b.

Lenaerts, J. T. M., van Meijgaard, E., van den Broeke, M. R., Ligtenberg, S. R. M., Horwath, M., and Isaksson, E.: Recent snowfall anomalies in Dronning Maud Land, East Antarctica, in a historical and future climate perspective, Geophys. Res. Lett., 40, 2684-2688, doi:10.1002/grl.50559, 2013.

Leonard, K. C., Tremblay, L. B., Thom, J. E., and MacAyeal, D. R.: Drifting snow threshold measurements near McMurdo station, Antarctica: A sensor comparison study, Cold Reg. Sci. Technol., 70, 71-80, doi:10.1016/j.coldregions.2011.08.001, 2012.

Ligtenberg, S. R. M., van de Berg, W. J., van den Broeke, M. R., Rae, J. G. L., and van Meijgaard, E.: Future surface mass balance of the Antarctic ice sheet and its influence on sea level change, simulated by a regional atmospheric climate model, Clim. Dynam., 41, 867-884, doi:10.1007/s00382-013-1749-1, 2013.

Liston, G. E., Bruland, O., Winther, J.-G., Elvehø, H., and Knut, S.: Meltwater production in Antarctic blue-ice areas: sensitivity to changes in atmospheric forcing, Polar Research, 18, 283-290, doi:10.1111/j.1751-8369.1999.tb00305.x, 1999.
Löhnert, U., Kneifel, S., Battaglia, A., Hagen, M., Hirsch, L., and Crewell, S.: A Multisensor Approach Toward a Better Understanding of Snowfall Microphysics: The TOSCA Project, B. Am. Meteorol. Soc., 92, 613-628, doi:10.1175/2010BAMS2909.1, 2011.

Maahn, M. and Kollias, P.: Improved Micro Rain Radar snow measurements using Doppler spectra post-processing, Atmos. Meas. Tech., 5, 2661-2673, doi:10.5194/amt-5-2661-2012, 2012.

Maahn, M., Burgard, C., Crewell, S., Gorodetskaya, I. V., Kneifel, S., Lhermitte, S., Van Tricht, K., and Van Lipzig, N. P. M.: How does the spaceborne radar blind zone affect derived surface snowfall statistics in polar regions?, J. Geophys. Res. Atmos., 119, 13604-13620, doi:10.1002/2014JD022079, 2014.

Mahesh, A., Walden, V. P., and Warren, S. G.: GroundBased Infrared Remote Sensing of Cloud Properties over the Antarctic Plateau - Part I: Cloud-Base Heights, J. Appl. Meteorol., 40, 1265-1278, doi:10.1175/15200450(2001)040<1265:GBIRSO>2.0.CO;2, 2001a.

Mahesh, A., Walden, V. P., and Warren, S. G.: Ground-Based Infrared Remote Sensing of Cloud Properties over the Antarctic Plateau - Part II: Cloud Optical Depths and Particle Sizes, J. Appl. Meteorol., 40, 1279-1294, doi:10.1175/15200450(2001)040<1279:GBIRSO>2.0.CO;2, $2001 \mathrm{~b}$.

Mahesh, A., Eager, R., Campbell, J. R., and Spinhirne, J. D.: Observations of blowing snow at the South Pole, J. Geophys. Res., 108, 4707, doi:10.1029/2002JD003327, 2003.

Mahesh, A., Campbell, J. R., and Spinhirne, J. D.: Multi-year measurements of cloud base heights at South Pole by lidar, Geophys. Res. Lett., 32, L09812, doi:10.1029/2004GL021983, 2005.

Marchand, R., Mace, G. G., Ackerman, T., and Stephens, G.: Hydrometeor Detection Using Cloudsat - An Earth-Orbiting 94-GHz Cloud Radar, J. Atmos. Ocean. Tech., 25, 519-533, doi:10.1175/2007JTECHA1006.1, 2008.

Masson-Delmotte, V., Hou, S., Ekaykin, A., Jouzel, J., Aristarain, A., Bernardo, R. T., Bromwich, D., Cattani, O., Delmotte, M., Falourd, S., Frezzotti, M., Gallée, H., Genoni, L., Isaksson, E., Landais, A., Helsen, M. M., Hoffmann, G., Lopez, J., Morgan, V., Motoyama, H., Noone, D., Oerter, H., Petit, J. R., Royer, A., Uemura, R., Schmidt, G. a., Schlosser, E., Simões, J. C., Steig, E. J., Stenni, B., Stievenard, M., van den Broeke, M. R., van de Wal, R. S. W., van de Berg, W. J., Vimeux, F., and White, J. W. C.: A Review of Antarctic Surface Snow Isotopic Composition: Observations, Atmospheric Circulation, and Isotopic Modeling, J. Climate, 21, 3359-3387, doi:10.1175/2007JCLI2139.1, 2008.

Matrosov, S. Y.: Modeling Backscatter Properties of Snowfall at Millimeter Wavelengths, J. Atmos. Sci., 64, 1727-1736, doi:10.1175/JAS3904.1, 2007.

Mohn, H.: Roald Amundsen's Antarctic expedition scientific results. Meteorology. (Videnskapsselskapets Skrifter. I. Mat.Naturv. Klasse 1915. No. 5), Tech. rep., Kristiania, I. Kommission Hos Jacob Dybwad., National Oceanic and Atmospheric Administration and the Climate Database Modernization Program, National Climate Data Center, Beltsville, MD, USA, available at: http://docs.lib.noaa.gov/rescue/IPY/IPY_020_pdf/ Qc9949M641915.pdf (last access: 4 February 2015), 1915.

Morley, B. M., Uthe, E. E., and Viezee, W.: Airborne lidar observations of clouds in the Antarctic troposphere, Geophys. Res. Lett., 16, 491-494, doi:10.1029/GL016i006p00491, 1989. 
Morrison, H. and Pinto, J. O.: Mesoscale modeling of springtime Arctic mixed-phase stratiform clouds using a new twomoment bulk microphysics scheme, J. Atmos. Sci., 62, 36833704, doi:10.1175/JAS3564.1, 2005.

Münkel, C., Eresmaa, N., Räsänen, J., and Karppinen, A.: Retrieval of mixing height and dust concentration with lidar ceilometer, Bound.-Lay. Meteorol., 124, 117-128, doi:10.1007/s10546-0069103-3, 2006.

Nott, G. J. and Duck, T. J.: Lidar studies of the polar troposphere, Meteorol. Appl., 18, 383-405, doi:10.1002/met.289, 2011.

O'Connor, E., Illingworth, A., and Hogan, R.: A Technique for Autocalibration of Cloud Lidar, J. Atmos. Ocean. Tech., 21, 777-786, doi:10.1175/15200426(2004)021<0777:ATFAOC>2.0.CO;2, 2004.

Pal, S. R., Steinbrecht, W., and Carswell, A. I.: Automated method for lidar determination of cloud-base height and vertical extent, Appl. Optics, 31, 1488-1494, doi:10.1364/AO.31.001488, 1992.

Palerme, C., Kay, J. E., Genthon, C., L'Ecuyer, T., Wood, N. B., and Claud, C.: How much snow falls on the Antarctic ice sheet?, The Cryosphere, 8, 1577-1587, doi:10.5194/tc-8-1577-2014, 2014.

Palm, S. P., Yang, Y., Spinhirne, J. D., and Marshak, A.: Satellite remote sensing of blowing snow properties over Antarctica, J. Geophys. Res., 116, D16123, doi:10.1029/2011JD015828, 2011.

Pattyn, F. and Decleir, H.: Satellite monitoring of ice and snow in the Sør Rondane Mountains, Antarctica, Ann. Glaciol., 17, 4148, 1993.

Pattyn, F., Matsuoka, K., and Berte, J.: Glacio-meteorological conditions in the vicinity of the Belgian Princess Elisabeth Station, Antarctica, Antarct. Sci., 22, 79-85, doi:10.1017/S0954102009990344, 2010.

Platt, C. M., Young, S. A., Carswell, A. I., Pal, S. R., McCormick, M. P., Winker, D. M., DelGuasta, M., Stefanutti, L., Eberhard, W. L., Hardesty, M., Flamant, P. H., Valentin, R., Forgan, B., Gimmestad, G. G., Jäger, H., Khmelevtsov, S. S., Kolev, I., Kaprieolev, B., Lu, D.-r., Sassen, K., Shamanaev, V. S., Uchino, O., Mizuno, Y., Wandinger, U., Weitkamp, C., Ansmann, A., and Wooldridge, C.: The Experimental Cloud Lidar Pilot Study (ECLIPS) for Cloud-Radiation Research, B. Am. Meteorol. Soc., 75, 1635-1654, doi:10.1175/15200477(1994)075<1635:TECLPS>2.0.CO;2, 1994.

Rasmussen, R. M., Vivekanandan, J., Cole, J., Myers, B., and Masters, C.: The Estimation of Snowfall Rate Using Visibility, J. Appl. Meteorol., 38, 1542-1563, doi:10.1175/15200450(1999)038<1542:TEOSRU>2.0.CO;2, 1999.

Rathke, C., Neshyba, S., Shupe, M., Rowe, P., and Rivers, A.: Radiative and microphysical properties of Arctic stratus clouds from multiangle downwelling infrared radiances, J. Geophys. Res., 107, 4703, doi:10.1029/2001JD001545, 2002.

Ricchiazzi, P., Gautier, C., and Lubin, D.: Cloud scattering optical depth and local surface albedo in the Antarctic : Simultaneous retrieval using ground-based radiometry, J. Geophys. Res., 100, 21091-21104, doi:10.1029/95JD01461, 1995.

Rignot, E., Velicogna, I., van den Broeke, M. R., Monaghan, A., and Lenaerts, J. T. M.: Acceleration of the contribution of the Greenland and Antarctic ice sheets to sea level rise, Geophys. Res. Lett., 38, L05503, doi:10.1029/2011GL046583, 2011.

Rusin, N. P.: Meteorological and Radiation Regime of Antarctica (Meteorologicheski i Radiatsionnyi Rezhim Antarktidy),
Gidrometeoizdat, Leningrad., 446 pp., available at: http://books . google.be/books?id=sr8JAQAAIAAJ, 1964.

Schlosser, E., Manning, K. W., Powers, J. G., Duda, M. G., Birnbaum, G., and Fujita, K.: Characteristics of high-precipitation events in Dronning Maud Land, Antarctica, J. Geophys. Res., 115, D14107, doi:10.1029/2009JD013410, 2010.

Sedlar, J., Shupe, M. D., and Tjernström, M.: On the Relationship between Thermodynamic Structure and Cloud Top, and Its Climate Significance in the Arctic, J. Climate, 25, 2374-2393, doi:10.1175/JCLI-D-11-00186.1, 2012.

Shiobara, M., Yabuki, M., and Kobayashi, H.: A polar cloud analysis based on Micro-pulse Lidar measurements at Ny-Alesund, Svalbard and Syowa, Antarctica, Phys. Chem. Earth, 28, 12051212, doi:10.1016/j.pce.2003.08.057, 2003.

Shupe, M. D.: Clouds at Arctic Atmospheric Observatories - Part II: Thermodynamic Phase Characteristics, J. Appl. Meteorol. Climatol., 50, 645-661, doi:10.1175/2010JAMC2468.1, 2011.

Shupe, M. D. and Intrieri, J. M.: Cloud radiative forcing of the Arctic surface: The influence of cloud properties, surface albedo, and solar zenith angle, J. Climate, 17, 616-628, doi:10.1175/15200442(2004)017<0616:CRFOTA>2.0.CO;2, 2004.

Shupe, M. D., Matrosov, S. Y., and Uttal, T.: Mixed-phase cloud properties derived from surface-based sensors at SHEBA, J. Atmos. Sci., 63, 697-711, doi:10.1175/JAS3659.1, 2006.

Shupe, M. D., Walden, V. P., Eloranta, E., Uttal, T., Campbell, J. R., Starkweather, S. M., and Shiobara, M.: Clouds at Arctic Atmospheric Observatories - Part I: Occurrence and Macrophysical Properties, J. Appl. Meteorol. Climatol., 50, 626-644, doi:10.1175/2010JAMC2467.1, 2011.

Shupe, M. D., Turner, D. D., Walden, V. P., Bennartz, R., Cadeddu, M. P., Castellani, B. B., Cox, C. J., Hudak, D. R., Kulie, M. S., Miller, N. B., Neely, R. R., Neff, W. D., and Rowe, P. M.: High and Dry: New Observations of Tropospheric and Cloud Properties above the Greenland Ice Sheet, B. Am. Meteorol. Soc., 94, 169-186, doi:10.1175/BAMS-D-11-00249.1, 2013.

Stephens, G. L., Vane, D. G., Boain, R. J., Mace, G. G., Sassen, K., Wang, Z., Illingworth, A. J., O'Connor, E. J., Rossow, W. B., Durden, S. L., Miller, S. D., Austin, R. T., Benedetti, A., Mitrescu, C., and CloudSat Science Team, T.: The CloudSat Mission and the A-Trains, B. Am. Meteorol. Soc., 83, 1771-1790, doi:10.1175/BAMS-83-12-1771, 2002.

Sun, Z. and Shine, K. P.: Studies of the radiative properties of ice and mixed-phase clouds, Q. J. Roy. Meteorol. Soc., 120, 111137, doi:10.1002/qj.49712051508, 1994.

Thiery, W., Gorodetskaya, I. V., Bintanja, R., Van Lipzig, N. P. M., Van den Broeke, M. R., Reijmer, C. H., and Kuipers Munneke, P.: Surface and snowdrift sublimation at Princess Elisabeth station, East Antarctica, The Cryosphere, 6, 841-857, doi:10.5194/tc-6841-2012, 2012.

Thomas, L., Cartwright, J. C., and Wareing, D. P.: Lidar observations of the horizontal orientation of ice crystals in cirrus clouds, Tellus, 42, 211-216, doi:10.1034/j.1600-0889.1990.00001.x-i1, 1990.

Town, M. S., Walden, V. P., and Warren, S. G.: Cloud Cover over the South Pole from Visual Observations, Satellite Retrievals, and Surface-Based Infrared Radiation Measurements, J- Climate, 20, 544-559, doi:10.1175/JCLI4005.1, 2007.

Turner, D. D., Vogelmann, A. M., Johnson, K., Miller, M., Austin, R. T., Barnard, J. C., Flynn, C., Long, C., McFarlane, S. A., 
Cady-Pereira, K., Clough, S. A., Chiu, J. C., Khaiyer, M. M., Liljegren, J., Lin, B., Minnis, P., Marshak, A., Matrosov, S. Y., Min, Q., O'Hirok, W., Wang, Z., and Wiscombe, W.: Thin Liquid Water Clouds: Their Importance and Our Challenge, B. Am. Meteorol. Soc., 88, 177-190, doi:10.1175/BAMS-88-2-177, 2007.

Turner, J. and Pendlebury, S. (Eds.): The international Antarctic Weather Forecasting Handbook, British Antarctic Survey, Cambridge, UK, available at: http://www.antarctica.ac.uk/met/momu/ International_Antarctic_Weather_Forecasting_Handbook/ (last access: 4 February 2015), 2004.

Uotila, P., Lynch, A. H., Cassano, J. J., and Cullather, R. I.: Changes in Antarctic net precipitation in the 21st century based on Intergovernmental Panel on Climate Change (IPCC) model scenarios, J. Geophys. Res., 112, D10107, doi:10.1029/2006JD007482, 2007.

Van den Broeke, M., As, D. V., Reijmer, C. H., and de Wal, R. S. V. V.: Surface radiation balance in Antarctica as measured with automatic weather stations, J. Geophys. Res., 109, D09103, doi:10.1029/2003JD004394, 2004.

Van den Broeke, M. R., Reijmer, C. H., and Wal, R. S. W. V. A. N. D. E.: A study of the surface mass balance in Dronning Maud Land, Antarctica, using automatic weather stations, J. Glaciol., 50, 565-582, doi:10.3189/172756504781829756, 2004.

Van den Broeke, M. R., Reijmer, C., Van As, D., and Boot, W.: Daily cycle of the surface energy balance in Antarctica and the influence of clouds, Int. J. Climatol., 26, 1587-1605, doi:10.1002/joc.1323, 2006.

Van den Broeke, M. R., Bamber, J., Lenaerts, J., and Rignot, E.: Ice Sheets and Sea Level: Thinking Outside the Box, Surv. Geophys., 32, 495-505, doi:10.1007/s10712-011-9137-z, 2011.

Van Tricht, K., Gorodetskaya, I. V., Lhermitte, S., Turner, D. D., Schween, J. H., and Van Lipzig, N. P. M.: An improved algorithm for polar cloud-base detection by ceilometer over the ice sheets, Atmos. Meas. Tech., 7, 1153-1167, doi:10.5194/amt-71153-2014, 2014.

Verlinde, J., Harrington, J. Y., Yannuzzi, V. T., Avramov, A., Greenberg, S., Richardson, S. J., Bahrmann, C. P., McFarquhar, G. M., Zhang, G., Johnson, N., Poellot, M. R., Mather, J. H., Turner, D. D., Eloranta, E. W., Tobin, D. C., Holz, R., Zak, B. D., Ivey, M. D., Prenni, A. J., DeMott, P. J., Daniel, J. S., Kok, G. L., Sassen, K., Spangenberg, D., Minnis, P., Tooman, T. P., Shupe, M., Heymsfield, A. J., and Schofield, R.: The Mixed-Phase Arctic Cloud Experiment, B. Am. Meteorol. Soc., 88, 205-221, doi:10.1175/BAMS-88-2-205, 2007.
Vihma, T., Mattila, O.-P., Pirazzini, R., and Johansson, M. M.: Spatial and temporal variability in summer snow pack in Dronning Maud Land, Antarctica, The Cryosphere, 5, 187-201, doi:10.5194/tc-5-187-2011, 2011.

Wacker, U., Ries, H., and Schättler, U.: Precipitation simulation for Dronning Maud Land using the COSMO Model, Antarct. Sci., 21, 643-662, doi:10.1017/S0954102009990149, 2009.

Walden, V. P., Warren, S. G., and Tuttle, E.: Atmospheric Ice Crystals over the Antarctic Plateau in Winter, J. Appl. Meteorol., 42, 1391-1405, doi:10.1175/15200450(2003)042<1391:AICOTA>2.0.CO;2, 2003.

Walden, V. P., Ellison, M. E., Brandt, R. E., Town, M. S., Hudson, S. R., and Jones, R. M.: Properties of Super-cooled water clouds over South Pole, in: Proceedings of the 8th Conference on Polar Meteorology and Oceanography, San Diego, CA, 9-13 January 2005, Am. Meteorol. Soc., 6.1, 2005.

Wang, Z. and Sassen, K.: Cloud Type and Macrophysical Property Retrieval Using Multiple Remote Sensors, J. Appl. Meteorol., 40, 1665-1682, doi:10.1175/15200450(2001)040<1665:CTAMPR>2.0.CO;2, 2001.

Wang, Z., Sassen, K., Whiteman, D. N., and Demoz, B. B.: Studying Altocumulus with Ice Virga Using Ground-Based Active and Passive Remote Sensors, J. Appl. Meteorol., 43, 449-460, doi:10.1175/1520-0450(2004)043<0449:SAWIVU>2.0.CO;2, 2004.

Westbrook, C. D. and Illingworth, A. J.: The formation of ice in a long-lived supercooled layer cloud, Q. J. Roy. Meteor. Soc., 139, 2209-2221, doi:10.1002/qj.2096, 2013.

Winker, D. M., Pelon, J., Coakley, J. A., Ackerman, S. A., Charlson, R. J., Colarco, P. R., Flamant, P., Fu, Q., Hoff, R. M., Kittaka, C., Kubar, T. L., Le Treut, H., McCormick, M. P., Mégie, G., Poole, L., Powell, K., Trepte, C., Vaughan, M. A., and Wielicki, B. A.: The CALIPSO Mission: A Global 3D View of Aerosols and Clouds, B. Am. Meteorol. Soc., 91, 1211-1229, doi:10.1175/2010BAMS3009.1, 2010. 